\title{
A review of the genus Neorbamnusium Hayashi, 1976 (Coleoptera: Cerambycidae), with descriptions of three new species
}

\author{
Обзор рода Neorbamnusium Hayashi, 1976 (Coleoptera: \\ Cerambycidae) с описанием трех новых видов
}

\author{
Alexandr I. Miroshnikov ${ }^{1,2} \&$ Mei-Ying Lin $^{3}$ \\ А.И. Мирошников ${ }^{1,2}$, М. $\Lambda и \mathrm{H}^{3}$
}

\author{
${ }^{1}$ Russian Entomological Society, Krasnodar, Russia. E-mail: miroshnikov-ai@yandex.ru \\ ${ }^{2}$ Sochi National Park, Moskovskaya str., 21, Sochi, Krasnodar region 354002, Russia. \\ ${ }^{3}$ Key Laboratory of Zoological Systematics and Evolution, Institute of Zoology, Chinese Academy of Sciences, 1 \# Beichen West Road, \\ Chaoyang, Beijing 100101. E-mail: linmeiying@ioz.ac.cn \\ 'Русское энтомологическое общество, Краснодар, Россия. \\ ${ }^{2}$ Сочинский национальный парк, ул. Московская, 21, Сочи, Краснодарский край 354000, Россия. \\ ${ }^{3}$ Ведущая лаборатория зоологической систематики и эволюции Института зоологии Китайской академии наук.
}

KEY WORDS: Coleoptera, Cerambycidae, Lepturinae, Rhamnusiini, Neorhamnusium, review, new species, key to species, China.

КЛЮЧЕВЫЕ СЛОВА: Coleoptera, Cerambycidae, Lepturinae, Rhamnusiini, Neorhamnusium, обзор, новые виды, таблица для определения видов, Китай.

ABSTRACT. A review is presented of the genus Neorhamnusium Hayashi, 1976, which until now has only been known from China, including Taiwan. The following three species are described as new: N. melanocephalum sp.n. (Yunnan Province), N. shaanxiensis sp.n. (Shaanxi Province) and N. wuchaoi sp.n. (environs of Beijing). Detailed diagnoses of, as well as a key to, all five species of the genus are given. In the type species of the genus, N. taiwanum Hayashi et Ando in Hayashi, 1976, some morphological features are clarified. A thorough redescription of $N$. rugosipenne (Pic, 1939) is given. The genus is rediagnosed and rediscribed. Abundant colour illustrations, including of the holotypes of all species, are provided.

РЕЗЮМЕ. Предлагается обзор рода Neorhamnusium Hayashi, 1976, до сих пор известного только из Китая, включая Тайвань. Описаны как новые $N$. melanocephalum sp.n. (Юньнань), N. shaanxiensis sp.n. (Шэньси) и N. wuchaoi sp.n. (окрестности Пекина). Для всех пяти видов рода даны подробные диагнозы. Для типового вида рода N. taiwanum Hayashi et Ando in Hayashi, 1976 уточнены некоторые морфологические особенности. Дано детальное описание N. rugosipenne (Pic, 1939). Предложена таблица для определения всех видов. Даны диагноз и описание рода. Представлено большое количество цветных иллюстраций, в том числе голотипов всех видов.

\section{Introduction}

The genus Neorhamnusium Hayashi, 1976 was originally established for a single Taiwanese species,
N. taiwanum Hayashi et Ando in Hayashi, 1976. Somewhat later, Hayashi, Villiers [1985] correctly transferred to this genus also Rhamnusium rugosipenne Pic, 1939, which had been described based on the male holotype from Shanxi Province, China. In addition to the male holotype, $N$. taiwanum is known from a female as well [Chou, 2004]. To the best of our knowledge, this seems to be all concerning the taxonomy of Neorhamnusium.

Prompted by the discovery of three new species from China, the present paper provides a review of the genus. One of the new species which stems from Yunnan Province differs very clearly from all congeners and significantly extends the morphological diversity of Neorhamnusium. The other two new species, from Shaanxi Province and Beijing, respectively, resemble $N$. rugosipenne, being less markedly distinct compared to the Yunnan form. The descriptions of all three new species are only based on holotypes taken by various collectors in 2011-2014.

The material this paper is based upon comes from the following institutional and private collections:

BMNH - Natural History Museum, London (formerly British Museum, Natural History), United Kingdom IZAS - Institute of Zoology, Chinese Academy of Sciences, Beijing, China

MNHN - Muséum national d'Histoire naturelle, Paris, France

OMNH - Osaka Museum of Natural History, Osaka, Japan

ZMUM - Zoological Museum of the Moscow State University, Moscow, Russia

cAM - coll. Alexandr Miroshnikov (Krasnodar, Russia) cSM - coll. Sergey Murzin (Moscow, Russia) 


\section{cWIC - coll. Wen-I Chou (Taitung, Taiwan).}

Genus Neorhamnusium Hayashi, 1976

Neorhamnusium Hayashi, 1976: 1. Hayashi, Villiers, 1985: 35; Hayashi et al., 1988: 172; Jiang, Chen, 2001: 224; Catalogue ..., 2010: 135

Type species: Neorhamnusium taiwanum Hayashi et Ando in Hayashi, 1976, by original desiganation.

DIAGNOSIS. This genus resembles the Western Palaearctic genus Rhamnusium Latreille, 1829, the only other member of the tribe Rhamnusiini (see Remarks), but differs clearly, at least in the male, by the longer and, in both sexes, slender antennae which show no antennomeres with a strongly expressed apical external angle, as well as by the peculiar shape of antennomere 5, the more or less strongly elongated antennomeres, starting with the $5^{\text {th }}$, the weakly developed setation consisting of long, erect setae on the sides of the pronotum, the more diverse shapes of the elytra which can be significantly broadened towards the apex in the apical part.

DESCRIPTION. Body length 17.0-21.7 mm. Dorsum almost entirely red or partly orange tones, but head and scutellum can be black; antennae and legs almost completely black or with presence of red tones, sometimes mostly.

Head moderately small or more strongly developed, together with prothorax variable in size relative to elytra; antennal tubercles well-developed; genae more or less long, can be much longer than transverse diameter of eye, clearly, sometimes roughly punctured; temples strongly expressed, obtusely angulate posteriorly, noticeably or clearly broadened backwards, mostly or partly sparsely, clearly, sometimes roughly punctured; with a clear or sharp, deep median groove between antennal tubercles and eyes; in area of occiput more or less strongly depressed; dorsally clearly punctured, sometimes quite coarsely; eyes moderately convex, with well-developed emargination and small, distinct ocelli; mandibles at external margin in general obtusely angulate, in apical part more or less rounded; submentum well-expressed, with a heterogeneous, mostly rugose sculpture, can be clearly excavated at least in female; antennae in male slightly or noticeably not reaching the apex of elytra, in female at least reaching the middle of elytra or very clearly not reaching their apex; antennomere 1 thickened and clearly curved, antennomere 2 from barely transverse to distinctly longitudinal, both antennomeres 3 and 4 strongly shortened, subsequent antennomeres to a varying degree strongly elongated, thereby antennomere 5 significantly broadened in apical part on external side and narrowed towards apex or, besides this, less strongly broadened on inner side and also narrowed towards apex, while antennomeres 6-11 moderately flattened, slightly curved.

Pronotum with very well-developed or less strongly developed conical lateral tubercles, due to which being strongly or clearly transverse, but width at base can be only slightly greater than or subequal to length; disk with a pair of large, more or less convex or dorsally flattened tubercles, each on sides of midline, as well as with a small median tubercle which can be weakly expressed or quite unnoticeable; with a clear, unequally distributed puncturation.

Scutellum clearly sunken between adjacent parts of elytra, more or less triangular, rounded at apex.

Elytra moderately or quite elongated, approximately parallel-sided, or in apical part considerably broadened towards apex; at apex widely rounded or truncate partly; each elytron with two longitudinal, clearly or weakly expressed ribs on disk; with a sharp, dense and confluent puncturation forming to varying degree developed rugose sculpture.
Prosternum in apical part with transverse folds, prosternal process narrow between coxae, at apex broadened; mesosternum with a rugose sculpture, mesosternal process not less than twice as broad as prosternal process between coxae; metasternum and visible sternites predominantly with a dense puncturation; last (visible) sternite with a more or less developed impression in apical part.

Legs slender, long; femora not claviform, only somewhat thickened; metatarsomere 1 noticeably longer than next two metatarsomeres combined.

COMPOSITION. The genus includes five species, three of which are described below as new.

DISTRIBUTION. China, including Taiwan.

REMARKS. Hayashi [1976], in the original description of Neorhamnusium, noted that "This new genus may stand between [the] Japanese Xenophyrama Bates (1884) and [the] European Rhamnusium Latreille (1829)", but later, Hayashi \& Villiers [1985] established a "Rhamnusium-Generic Group" to incorporate these three genera. However, in the latest Catalogue [2010] the tribe Rhamnusiini includes only the genera Rhamnusium and Neorhamnusium, while the monotypic genus Xenophyrama is considered within the tribe Lepturini. A discussion of the systematic position of Xenophyrama lies beyond the scope of this paper, yet it seems noteworthy that Neorhamnusium differs very clearly from Xenophyrama, even much stronger than from Rhamnusium, in a whole number of features. In particular, these concern certain details of the structure of the head and prothorax, as well as the sculpture of the elytra. We have examined several males and females of $X$. purpureum Bates, 1884, kept in the BMNH and MNHN collections, as well as a large number of specimens of some forms of Rhamnusium kept in the ZMUM collection, cAM and cSM.

Neorhamnusium taiwanum Hayashi et Ando in Hayashi, 1976

Figs 1-3, 5, 27.

Neorhamnusium taiwanum Hayashi et Ando in Hayashi, 1976: 2. Type locality: Taiwan (according to the original description). Hayashi, Villiers, 1985: 36, pl. 6, fig. 17; Hayashi et al., 1988: 173; Jiang, Chen, 2001: 224; Chou, 2004: 74; Mizuno, Shiyake, 2004: 7 , pl. 1; Wang, Hua, 2009: 177; Catalogue ..., 2010: 135.

MATERIAL. Holotype or (OMNH) (photograph; Fig. 1), "Holotype Neorhamnusium taiwanum Hayashi et Ando", "M. Hayashi Coll. OMNH [98-32]", "Genitalia 212” (Fig. 2) (see Remarks); 1 우 (cWIC) (photograph; Fig. 3), Taiwan, Taizhong County (Taichung), Wulingnongchang, 5.V.1999, leg. Mu-Xiang Su; 1 o (cWIC), Taiwan, Hualian County, Kalabao, 26.VI.2004, leg. Kun-Fang Lin.

DIAGNOSIS. This species, 20.2-22.7 $\mathrm{mm}$ in body length, is characterized by the elytra being quite elongated and considerably broadened towards the apex in the apical part, with clearly expressed, longitudinal ribs on the disk, a distinct rugose sculpture and a golden reddish pubescence, the pronotum with well-developed lateral tubercles, the widely spaced, large, dorsally more or less flattened discal tubercles and strong glossy shine, the long antennae in both sexes, the dorsally completely red body, the entirely or almost completely black or, partly, brown- black antennae, metasternum and visible sternites, and the mostly black legs. By the shape of the elytra, $N$. taiwanum can be compared to $N$. melanocephalum sp.n., but differs very clearly by characters listed below in both diagnosis and description of this species, i.e. primarily by the shape of the lateral tubercles of the pronotum, the coloration of the head, scutellum and, partly, legs, the length of the antennae, at least so in the female. Besides the shape of the elytra, $N$. taiwanum differs from other congeners at least by the entirely black tibiae, as well as in a combination of some other features. 

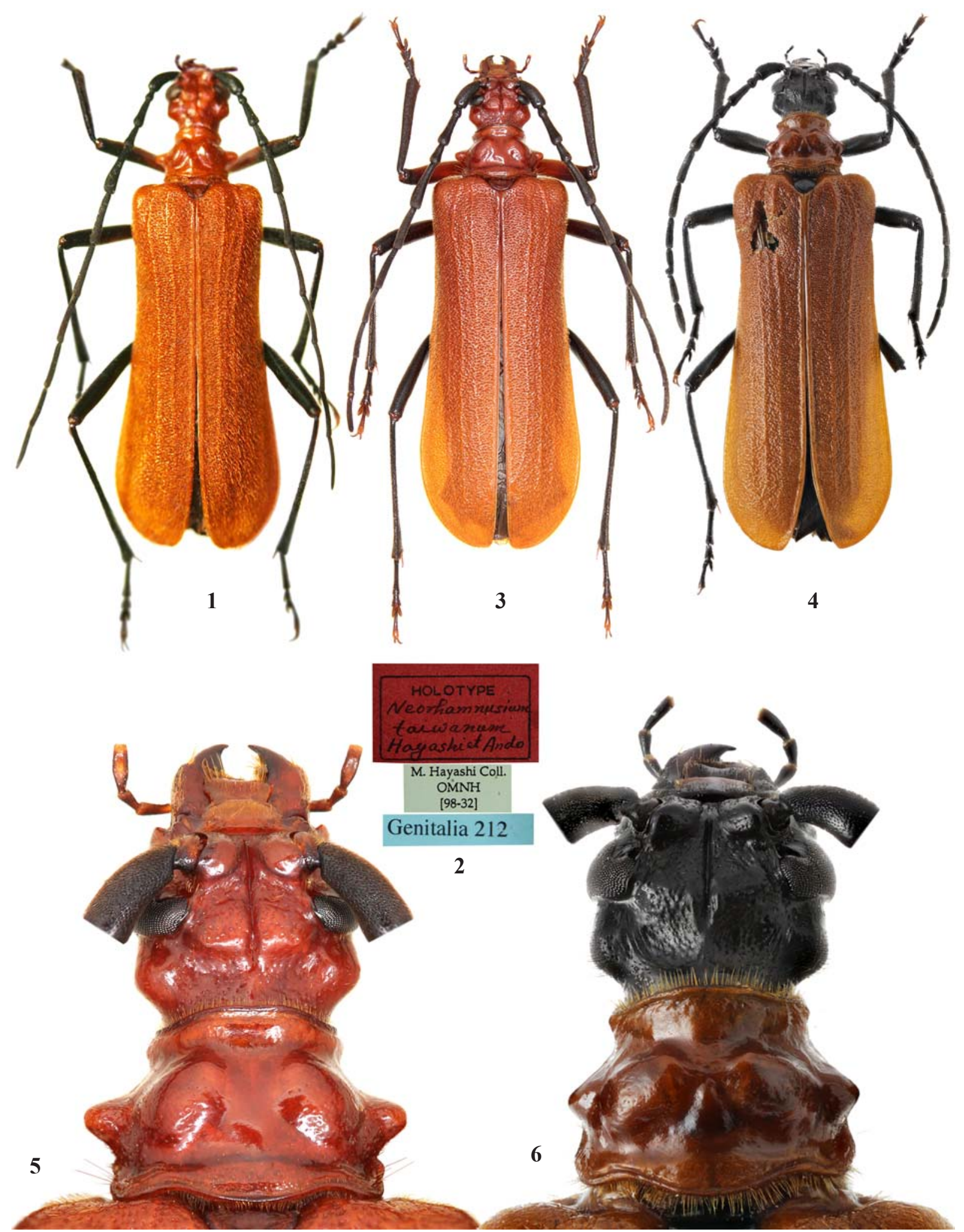

Figs 1-6. Neorhamnusium ssp.: 1-3,5-N. taiwanum; 4, 6-N. melanocephalum sp.n.; 1, 3, 4- habitus; 2 - labels of the holotype; 5, 6- head and pronotum, dorsral view; 1 - holotype male; 3,5 - female; 4, 6 - holotype female $(1,3,5$ - photographs by Nobuo Ohbayashi; 2 - photograph by Shigehiko Shiyake).

Рис. 1-6. Neorhamnusium ssp.: 1-3, 5- N. taiwanum; 4, 6-N. melanocephalum sp.n.; 1, 3, 4- общий вид; 2 - этикетки голотипа; 5, 6 - голова и переднеспинка, вид сверху; 1 - голотип, самец; 3,5 - самка; 4,6 - голотип, самка $(1,3,5$ - фотографии Нобуо Обаяси; 2 - фотография Сигехико Шияке). 
MORPHOLOGICAL NOTES. The original description of this species, based on a single male, is sufficiently detailed [Hayashi, Ando in Hayashi, 1976]. Below are just a few additions and clarifications which also take into account new material.

Through the courtesy of Dr. Wen-I Chou (Taitung, Taiwan), Dr. Nobuo Ohbayashi (Kamimiyada, Miura City, Japan) and Mr. Shigehiko Shiyake (OMNH), we have been privileged to obtain high-quality pictures of a male and a female, collected in Taizhong and Hualian counties of Taiwan, as well as some photographs of the holotype.

Based on the pictures of the holotype (Fig. 1) and the other male, in the antennae somewhat fail to reach the apex of the elytra, while at least the profemora (but probably the mesofemora as well) partly red tone, but not entirely black. The body length of the non-type male is $20.2 \mathrm{~mm}$.

The female (Figs 3, 5), for the first time published by Chou [2004], is very similar to the male, including by the proportions and sculpture of the elytra, and the location and sculpture of the discal tubercles of the pronotum, but differs at least by shorter antennae which almost reach the distalmost one-fifth of the elytra, and a somewhat wider prothorax. The pro- and mesofemora are partly red. The body length is 22.7 $\mathrm{mm}$.

DISTRIBUTION. Taiwan. Until now, only two accurate localities are known (see Material).

BIONOMICS. According to Chou [2004], this spesies lives in the mixed coniferous-broadleaved forests at an elevation about $2000 \mathrm{~m}$. Adults emerge during May to June, active in the daytime, feed on a sap of the trees. One female has been found at the area of the trunk of Quercus variabilis Blume, 1850 with the flowing juice.

REMARKS. The labels accompanying the holotype (Fig. 2) contain no information whatever on the place of origin, but the original description noted: "Taiwan, no further detailed data" [Hayashi, Ando in Hayashi, 1976].

\section{Neorhamnusium melanocephalum \\ Miroshnikov et Lin, sp.n.}

Figs 4, 6, 20, 26.

MATERIAL. Holotype 9 (cSM), China, Yunnan Prov., Laojunshan, river above Shangliju, $2755 \mathrm{~m}, 26^{\circ} 45^{\prime} 20^{\prime \prime} \mathrm{N} / 99^{\circ} 37^{\prime} 16^{\prime \prime} \mathrm{E}$, 25.VI.2014, leg. I. Belousov \& I. Kabak.

DIAGNOSIS. This new species differs very clearly from congeners at least by the considerably or distinctly less strongly developed lateral tubercles of the pronotum, the mostly black head and entirely black scutellum, femora and tibiae, as well as by antennomere 5 being somewhat broadened in the apical part in a peculiar way. Moreover, it differs from $N$. taiwanum in the shorter antennae, at least so in the female, and by many antennomeres being less strongly elongated and the legs shorter. Neorhamnusium melanocephalum sp.n. differs from remaining congeners by the elytra being considerably broadened towards the apex in the apical part, the head and pronotum smaller relative to the elytra, combined with a whole number of other characters described below.

DESCRIPTION. Female. The holotype lacks the right last mesotarsomere and part of the penultimate mesotarsomere, as well as part of the femur, tibia and tarsus of the right posterior leg; the left elytron at the base is severely damaged, the left antennomere 9 is deformed on the external side.

Body length $21.7 \mathrm{~mm}$, humeral width $6.2 \mathrm{~mm}$. Head, except for ventral side partly, palpi almost entirely, mandibles mostly, eyes, antennae, scutellum, metasternum and visible sternites complete, mesosternum and legs almost en- tirely black; the very base of trochantera of anterior and middle legs and all last tarsomeres apically lighter; pronotum, except for partly blackish discal median tubercle orange-red; mesosternum along basal margin and in apical part of process, mouthparts partly yellow tones; submentum almost entirely dark red-brown, only near gula orange; gula almost complete orange; pronotum with a stronger glossy shine than on head and elytra.

Head comparatively small, at least together with prothorax not appearing large relative to elytra; with well-developed antennal tubercles; in area of occiput very strongly depressed forming widely rounded outlines near border with temples and a clear boundary with neck; with a sharp median groove transformed in area of depression into a keel-shaped elevation and separating depression area into two equal parts; dorsally with heterogeneous, partly dense and even confluent, predominantly rough and moderately coarse mainly in area of depression punctures, in places forming rugose sculpture; genae well-developed, in length subequal to transverse diameter of eye, with a clear, moderately shallow puncturation; temples noticeably longer than genae, clearly broadened backwards, with most strongly developed punctures only posteriorly and ventrally; eyes emarginate to depth not more than $1 / 3$ of their transverse diameter; mandibles at external margin in middle part with a poorly developed step-shaped protrusion; submentum well-expressed, mainly excavated, most clearly at anterior margin and much weaker on sides, with a clear, transverse groove before gula at distance from it subequal to half of its length, predominantly with a clear rugose sculpture; gula with individual, transverse folds; on either side lateral to gula with very sharp, transverse folds, on either side lateral to submentum with clear, predominantly rough, partly rugose punctures; antennae extended barely behind middle of elytra; antennomere 2 longitudinal; antennomere 5 longest, considerably broadened in apical part on external side and less strongly, somewhat asymmetrically on inner side and narrowed towards apex on both sides; length ratio of antennomeres 1-11, 57: 24: 52: 30: 75: 62: 65: 55: 56: 54: 58 .

Pronotum clearly transverse, at level of lateral tubercles 1.4 times as wide as long; base 1.25 times as wide as long and 1.3 times as wide as width at apex; length only slightly exceeding width at apex; with moderately developed lateral tubercles so that elytra at humeri 1.8 times as wide as pronotum at their level; disk with a pair of large tubercles flanking midline, also with a small median tubercle; with a weak puncturation, more or less clear only at apex, base and partly on discal tubercles, except for median tubercle.

Scutellum mostly noticeably sunken between adjacent parts of elytra, subequal in length and width at base; moderately narrowed towards apex where rounded, distinctly impressed on sides in middle part and at apex, with a shallow, heterogeneous puncturation.

Elytra 2.65 times as long as humeral width; in basal part clearly narrowed towards apex over less than one-quarter of elytral length, thereafter considerably broadened towards apex; maximum width before apex almost 1.2 times as wide as humeral width; lateral to scutellum tuberculiform elevated; humeral angle widely rounded; on external sides of apex widely rounded; sutural angle narrowly rounded; very strongly diverging along suture at apex; each elytron with two wellexpressed ribs on disk and a sharp subsutural rib all along; with a sharp, dense and confluent puncturation forming clear, irregular, rugose sculpture especially well-developed approximately in apical one-third.

Prosternum in apical part with sharp, transverse folds, prosternal process narrow between coxae, considerably broa- 

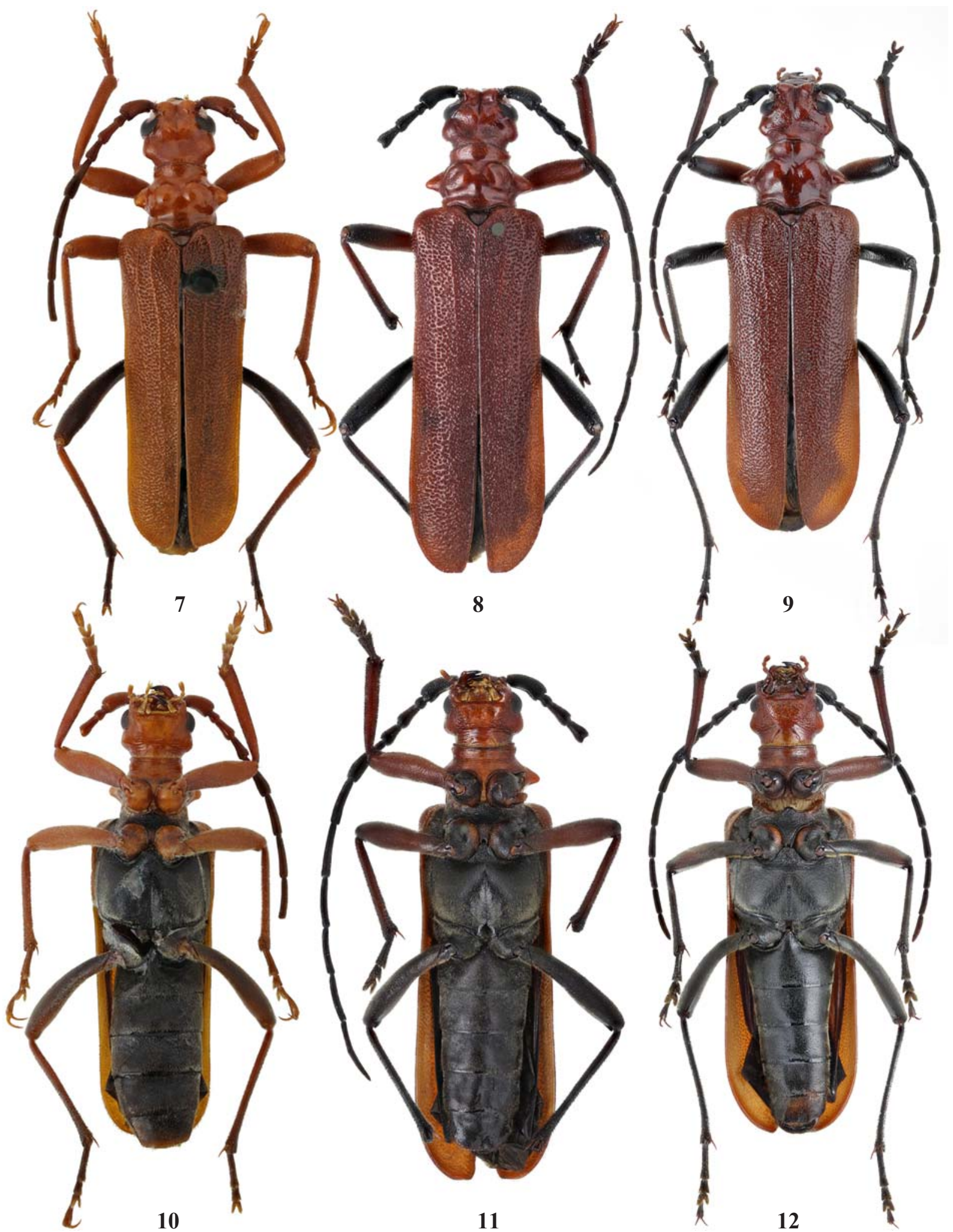

Figs 7-12. Neorhamnusium ssp., holotypes: 7, $10-N$. rugosipenne; 8, $11-N$. shaanxiensis sp.n.; 9, $12-N$. wuchaoi sp.n.; 7-9 habitus, dorsral view; 10-12 - habitus, ventral view; 7-8, 10-11 - males; 9, 12 - female.

Рис. 7-12. Neorhamnusium ssp., голотипы: 7, $10-N$. rugosipenne; 8, $11-N$. shaanxiensis sp.n.; 9, $12-N$. wuchaoi sp.n.; 7-9 общий вид сверху; 10-12 - общий вид снизу; 7-8, 10-11 - самцы; 9, 12 - самка. 
dened at apex; mesosternal process almost 4 times as wide as prosternal process between coxae; metasternum with a clear, small, dense, noticeably heterogeneous puncturation; visible sternites with same, but more uniform puncturation; last (visible) sternite at apex roundish, clearly impressed predominantly in apical part.

Legs slender, long; femora not claviform; metatarsomere 1 noticeably longer than next two metatarsomeres combined.

Sparse, more or less long, erect, light setae mainly on head and sides of pronotum; temples and, partly, head ventrally with abundant, erect, dark setae, these being shorter than on head and pronotum; both apical and basal margins of pronotum with moderately long, strongly expressed, abundant, golden setae, less strongly developed along margins of prosternum; elytra mainly with relatively short, suberect, sparse, golden-reddish setae; venter beset with predominantly recumbent, partly suberect, dull setae; setation of antennae and legs developed moderately.

DISTRIBUTION. China: Yunnan Province.

BIONOMICS. The holotype was taken in late June during a night catch at an altitude of about $3000 \mathrm{~m}$.

ETYMOLOGY. The name of the new species derives from Greek and means "black-headed", this being unusual for members of the genus Neorhamnusium.

Neorhamnusium rugosipenne (Pic, 1939)

Figs 7, 10, 13, 15, 17, 21, 23, 28, 31, 34, 37, 39, 41, 43.

Rhamnusium rugosipenne Pic, 1939: 2. Type locality: China Shanxi Province, Tsiliyu (= "Tsi Li Yu") (now Qiliyu; see Remarks) (according to the original description and the label of the holotype) Gressitt, 1951: 55; Hua, 1982 : 18; Cebeci, Özdikmen, 2010: 136

Neorhamnusium rugosipenne: Hayashi, Villiers, 1985: 37, pl 6, fig. 18; Hua, 2002 : 218; Wang, Hua, 2009: 177; Catalogue ..., 2010: 135 .

MATERIAL. Holotype $\sigma^{7}$, by monotypy (MNHN), "[China] Chansi S.O., 28 VI [19]35" (upperside) + "Licent" (underside), "Tsi Li Yu, 2100 m", "Muséum Paris, Coll. E. Licent", "584”, "Rhamnusium rugosipenne n.sp.", "Holotype" (Fig. 15) + "The type specimen is restored by A. Miroshnikov in 2015".

DIAGNOSIS. Together with two new taxa described below, $N$. rugosipenne forms a group of species with more or less parallel-sided elytra, a well-developed head which, together with the prothorax, fail to appear small relative to the elytra, and a variable, but always significant presence of red tones in the coloration of the legs. By these characters, $N$. rugosipenne differs clearly, in addition to the other features noted below, from both $N$. taiwanum and $N$. melanocephalum sp.n. The distinctions between $N$. rugosipenne and the following new species, both similar, are given in their diagnoses, lying in the structure of the head, prothorax, elytra, last (visible) sternite and genitalia.

DESCRIPTION. Holotype male. The holotype lacks the left antennomeres 9-11, right antennomeres 4-11 and left last metatarsomere.

Body length $17.0 \mathrm{~mm}$, humeral width $4.8 \mathrm{~mm}$. Head almost entirely, mouthparts, except for blackish apex of mandibles, antennomeres 1-4 complete, antennomere 5 in basal part, pronotum, except for blackish apical margin, scutellum and elytra entirely, prosternum, except for dark spots at base of process, mesosternum partly, anterior and middle legs, except for partly infuscate coxae, metafemora ventrally, metatibiae, except for an infuscate apex, two last metatarsomeres red tones; eyes entirely, mesosternum mostly, metasternum almost complete, visible sternites partly, metacoxae mostly black; antennomere 5 in apical part, remaining subsequent antennomeres (see Remarks), visible sternites mostly, metafemora, except for ventral side, metatibiae apically, two first metatarsomeres reddish-brown or brown; both head dorsally and pronotum with a strong, elytra with a weaker, glossy shine.

Head medium-size, at least together with prothorax not appearing small relative to elytra; with well-developed antennal tubercles; in area of occiput moderately strongly depressed, behind temples insensibly merging with neck; with a distinct, narrow, median groove between antennal tubercles and eyes; dorsally with a clear, small and, partly, moderately rough, not sharply expressed puncturation predominantly on occiput and near inner margin of eyes; genae moderately long, only barely longer than transverse diameter of eye and subequal to temples, with a clear, somewhat heterogeneous puncturation, denser in upper part, rugose partly near lower margin of eyes; temples moderately long, noticeably broadened backwards, mostly with very sparse, predominantly weakly expressed punctures; eyes emarginate to depth not more than $1 / 3$ of their transverse diameter; mandibles at external margin in middle part with a barely noticeable step-shaped protrusion; submentum most clearly depressed only at anterior margin, more or less flat mainly, with clear, moderately sparse punctures, on sides with well-expressed transverse wrinkles, decreasing in width towards gula; gula, partly, with gentle, transverse wrinkles; on either side lateral to gula and lower part of submentum with rough folds, on either side lateral to most of submentum with a heterogeneous, moderately sparse, mainly rough puncturation, without clear folds and wrinkles; antennae most likely approximately reaching the last one-fifth of elytra (see Remarks); antennomere 2 barely longitudinal; antennomere 5 considerably broadened in apical part on external side and narrowed towards apex; length ratio of antennomeres 1-8 (see above), 57: 17: 36: 34: 66: 64: 65: 62 .

Pronotum clearly transverse, at level of lateral tubercles 1.38 times as wide as long; base barely wider than long and 1.34 times as wide as width at apex; 1.27 times as long as width at apex; with well-developed lateral tubercles so that elytra at humeri 1.38 times as wide as pronotum at their level; disk with a pair of large, strongly convex, connivent tubercles flanking midline, also with a small, weakly noticeable, median tubercle; large discal tubercles on external side only slightly impressed; without median groove; with a small, somewhat heterogeneous puncturation, most clear at base, apex and on external side of discal tubercles, very sparse, partly or completely invisible in central part of disk, including both on inner and dorsal sides of discal tubercles.

Scutellum deeply sunken between adjacent parts of elytra, triangular, rounded at apex, in apical part noticeably impressed, with individual, unclear punctures.

Elytra 2.57 times as long as humeral width; barely narrowed towards apex; lateral to scutellum tuberculiform elevated; on external sides of apex widely rounded; sutural angle narrowly rounded; noticeably diverging along suture at apex; each elytron with two well-expressed ribs on disk and clear subsutural rib after its first one-third; with a sharp, dense and confluent puncturation forming mostly clear, predominantly transverse, rugose sculpture.

Prosternum in apical part with sharp, transverse folds, prosternal process narrow between coxae, considerably broadened at apex; mesosternum mainly with a rough, transversely rugose sculpture, mesosternal process almost 3 times as wide as prosternal process between coxae, with clear, sparse punctures; metasternum with a clear, predominantly small, dense puncturation forming at median suture, in its basal part, oblique wrinkles; most of visible sternites with a less distinct puncturation than on metasternum; last (visible) sternite at apical margin on either side of midline symmetrically ob- 


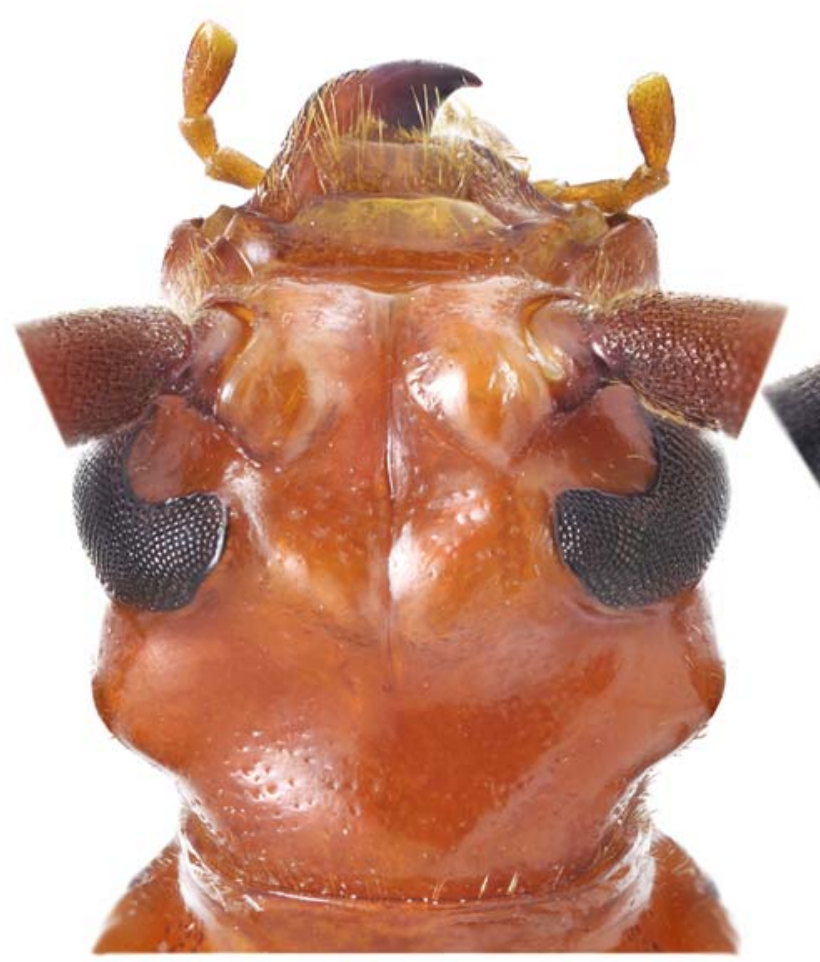

13

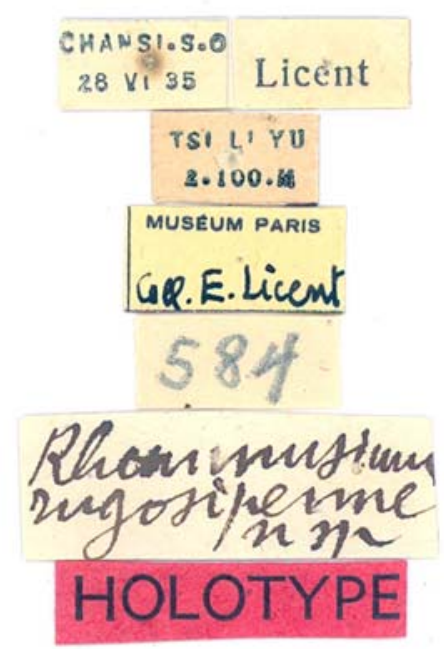

15

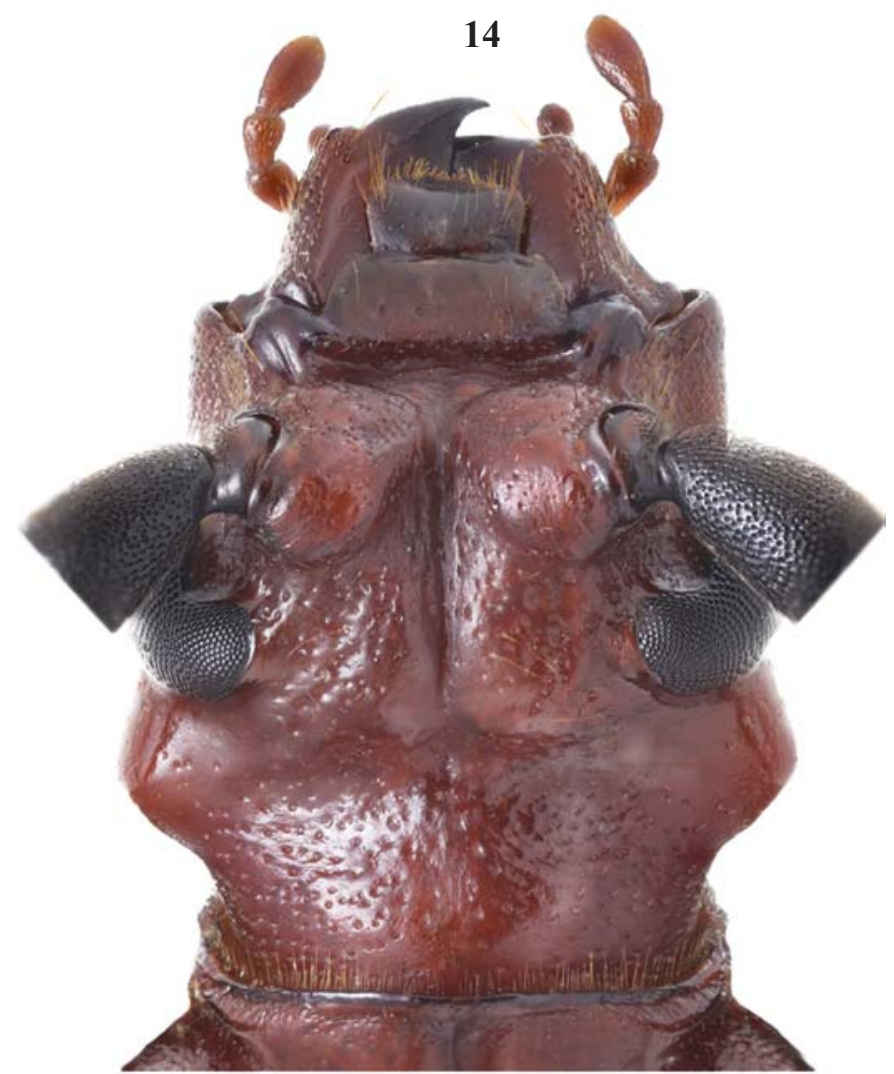

16

Figs 13-16. Neorhamnusium ssp., holotypes: $13,15-N$. rugosipenne; $14-N$. shaanxiensis sp.n.; $16-N$. wuchaoi sp.n.; 13-14, 16 - head, dorsral view; 15 - labels; $13-14$ - males; 16 - female.

Рис. 13-16. Neorhamnusium ssp., голотипы: 13, $15-$ N. rugosipenne; $14-N$. shaanxiensis sp.n.; $16-N$. wuchaoi sp.n.; 13-14, 16 - голова, вид сверху; 15 - этикетки; 13-14 - самцы; 16 - самка. 
liquely truncate forming a very obtuse angle, on sides obtusely angulate, noticeable impressed in apical part, with a distinct, somewhat heterogeneous, mostly rather dense, predominantly similar, relatively small puncturation as on previous sternite.

Legs slender, long; femora not claviform; metatarsomere 1 clearly longer than next two metatarsomeres combined.

Sparse, more or less long, erect, light setae mainly on head and sides of pronotum; both apical and basal margins of prothorax with abundant, yellowish and golden setae; elytra mainly with relatively short, suberect, sparse, golden-reddish setae; venter beset with numerous, predominantly recumbent, partly suberect, light setae; setation of antennae and legs developed moderately.

Genitalia. Tergite 8 significantly narrowed towards apex, at apical margin moderately wide, slightly rounded, on sides of apical margin more roundish than angulate, as in Fig. 37; penis (median lobe) strongly and unequally curved in lateral view, thereby about both in basal and second thirds obtusely angular, in apical one-third hamately curved, as in Fig. 43; tegmen as in Fig. 41, each paramere (lateral lobe) rather narrow, on inner side 8.8 times as long as width in the middle of apical one-third, on inner side rather straight, in apical part predominantly with long and very long, light setae, as in Figs $39,41$.

DISTRIBUTION. China: Shanxi Province.

BIONOMICS. The holotype was collected in late June at an altitude of about $2100 \mathrm{~m}$.

REMARKS. The total length of the antennae of the holotype is presumed based on the extrapolation of the proportions of antennomeres 6-8 and 9-11 in the holotype male of one of the new similar species described below.

The holotype might have stemmed from a somewhat remote locality in the environs of Qiliyu, the only probable place lying at an altitude of about $2100 \mathrm{~m}\left(\approx 36^{\circ} 38^{\prime} 19^{\prime \prime} \mathrm{N} /\right.$ $111^{\circ} 57^{\prime} 41^{\prime \prime} \mathrm{E}$ ) (according to the altitude given on one of the labels accompanying the holotype, see Fig. 15), less likely from Qiliyu and its immediate vicinities which lie only at about $1000-1200 \mathrm{~m}$ a.s.1. $\left(36^{\circ} 36^{\prime} \mathrm{N} / 111^{\circ} 58^{\prime} \mathrm{E}\right)$.

The route of Licent's trips in Shanxi Province, according to his notebook [Etapes ..., 1984], provides exact dates of his stay in those or other places during the middle of June to the second half of July 1935. He traveled from Lou ngan fou (now Lu'anfu; Changzhi City) (14.VI) to Fong yi (now Fengyi; Zhangzi County, Fengyizhen) (17.VI), then to Leang ma (now Liangma; Anze County, Liangmaxiang) (18.VI) and Houng ts'ounn (dubious name, possibly Hechuanzhen) (19.VI), followed by Ts'ong yu ts'ounn (now Zhongyu; Qinyuan County, Zhongyuxiang) (20.VI), Linn k'oung chan (now Lingkongshan) (21.VI), Tsi li yu (now Qiliyu; Linfen, Huozhou City) (28.VI), and Ho chan (now Huoshan; Huozhou City) (22.VII).

Neorhamnusium shaanxiensis Miroshnikov et Lin, sp.n. Figs 8, 11, 14, 18, 22, 24, 29, 32, 36, 38, 40, 42, 44.

MATERIAL. Holotype $\sigma^{\top}$ [IZAS, IOZ(E)1904799], China, Shaanxi Prov., Qinling, Ningshan, Huoditang, $33^{\circ} 25^{\prime} \mathrm{N} / 108^{\circ} 27^{\prime} \mathrm{E}$ VII.2011; YQ08 No.2

DIAGNOSIS. This new species resembles $N$. rugosipenne, but differs in the structure of the pronotum, including its being wider, the very peculiar ratios of the length, the breadth at the level of the lateral tubercles, the width at the base and apex, as well as by the clearly distinct ratio of width at the level of the lateral tubercles and width of the elytra at the humeri, the tubercles being more strongly narrowed towards the apex (Figs 28-29); the pronotum is also distinguished by a pair of much less strongly convex discal tubercles which are less connivent with each other (Figs 34, 36), strongly impressed on the external side and bearing a clearly coarser puncturation (Figs 28-29, 31-32), as well as in the wellexpressed, small, median discal tubercle; the elytra are more strongly elongated, somewhat deviating in shape of their apex (Figs 7-8,22), with a more sharply expressed transverse rugosity of sculpture, especially in the apical part; additional differences are observed in the structure of the last (visible) sternite, in particular, the sharper impression in its apical part, the character of puncturation, the shape of the apical margin (Figs 21-22); the more oblique apex of the last segment of the maxillary palpi (Figs 13-14, 23-24); the more angulate external margin of the mandibles and a clearer, tuberous, step-shaped protrusion in the middle part (Figs 1314, 23-24); the somewhat particular shape of tergite 8 , the less strongly and quite evenly curved penis, each paramere being clearly wider, distinctly not straight on inner side (Figs $37-44$ ); the rather dull (not glossy) shine of the pronotum and most of the head (Figs 13-14, 28-29, 31-32); the entirely black antennae, the profound presence of black in the coloration of the legs (Figs 7-8, 10-11). Neorhamnusium shaanxiensis sp.n. can also be compared to $N$. wuchaoi sp.n., but differs by the characters noted below in the diagnosis of the latter species, some of which are shared with the distinctions from $N$. rugosipenne, including the shape of the pronotum, the structure of its discal tubercles, the ratio of the length and width of the elytra, the shape of their apex, their sculpture, and the character of the shine of the head and pronotum.

DESCRIPTION. Male. In the holotype lacks the left antennomeres 5-11, anterior left leg, left mesotarsus, both metatarsi, last right mesotarsomere and left maxillary palpus.

Body length $19.0 \mathrm{~mm}$, humeral width $5.2 \mathrm{~mm}$. Head almost entirely, mouthparts partly, pronotum, except for blackish apical margin complete and basal margin in middle part, scutellum, except for blackish apical margin, elytra entirely, prosternum, except for apical margin mostly and process at apex, metasternum, pro- and mesocoxae partly, profemora, except for black apex, mesofemora mostly, protibiae complete, mesotibiae, except for blackish apex, last protarsomere (probably last meso- and metatarsomeres; see above) almost entirely red tones; eyes and antennae entirely, mandibles apically, mesosternum mostly, metasternum complete, visible sternites, except for reddish last one in apical part predominantly on sides, pro- and mesocoxae mostly, metacoxae entirely, mesofemora in basal one-third predominantly on inner side and at the very apex, metafemora and metatibiae, except for reddish base ventrally, pro- and mesotarsi (and probably metatarsi; see above), except for last tarsomere black; both head dorsally and pronotum with a rather dull shine, elytra with a moderate shine as well.

Head medium-size, at least together with prothorax not appearing small relative to elytra; with well-developed antennal tubercles; in area of occiput moderately strongly depressed, with a sharp, deep, median groove between antennal tubercles and eyes; dorsally with a clear puncturation predominantly on occiput and near inner margin of eyes; genae moderately long, barely shorter than transverse diameter of eye and noticeably shorter than temples, with a clear, rough, partly dense puncturation; temples comparatively long, noticeably broadened backwards, with sparse, clear punctures; eyes emarginate to depth not more than $1 / 3$ of their transverse diameter; mandibles at external margin in middle part with a clear, tuberous, step-shaped protrusion; submentum most clearly depressed only at anterior margin, mainly more or less flat, with irregular, rugose sculpture and individual punctures; gula with well-developed, transverse folds; 

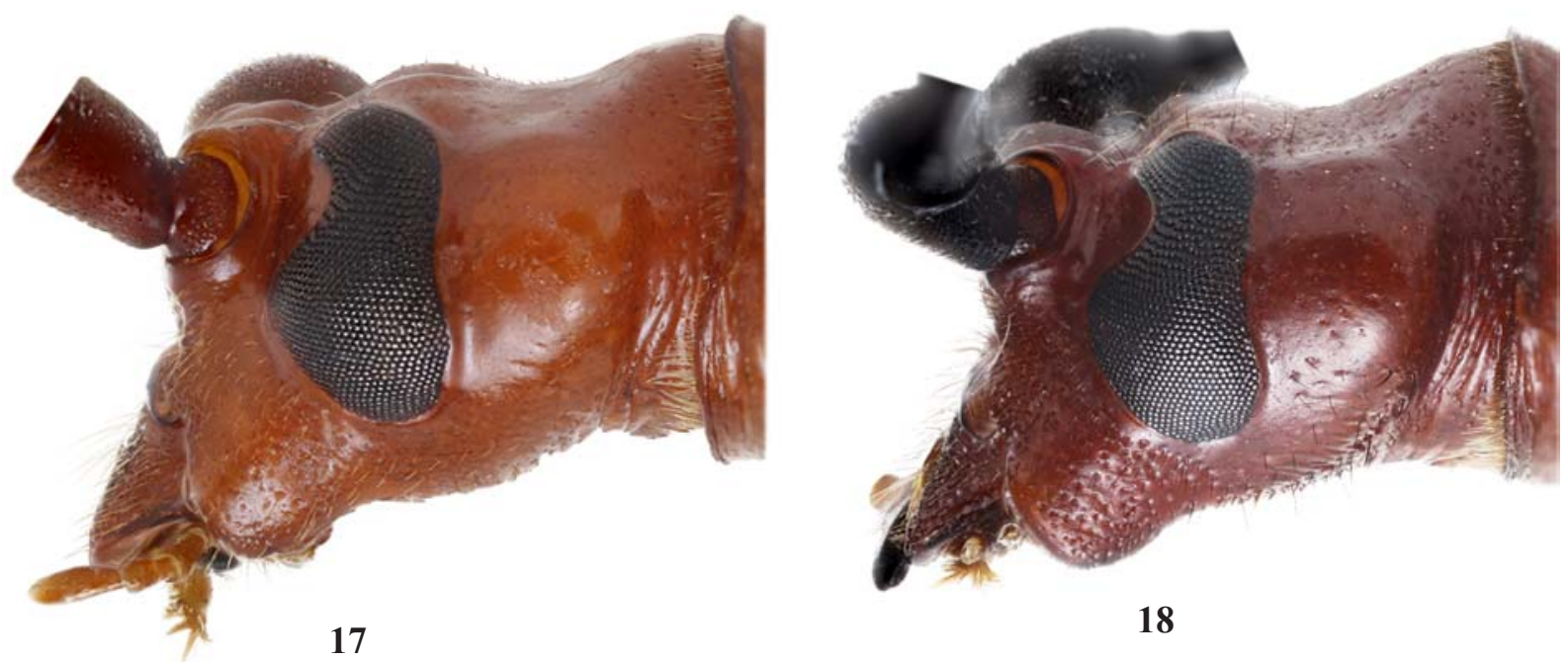

18
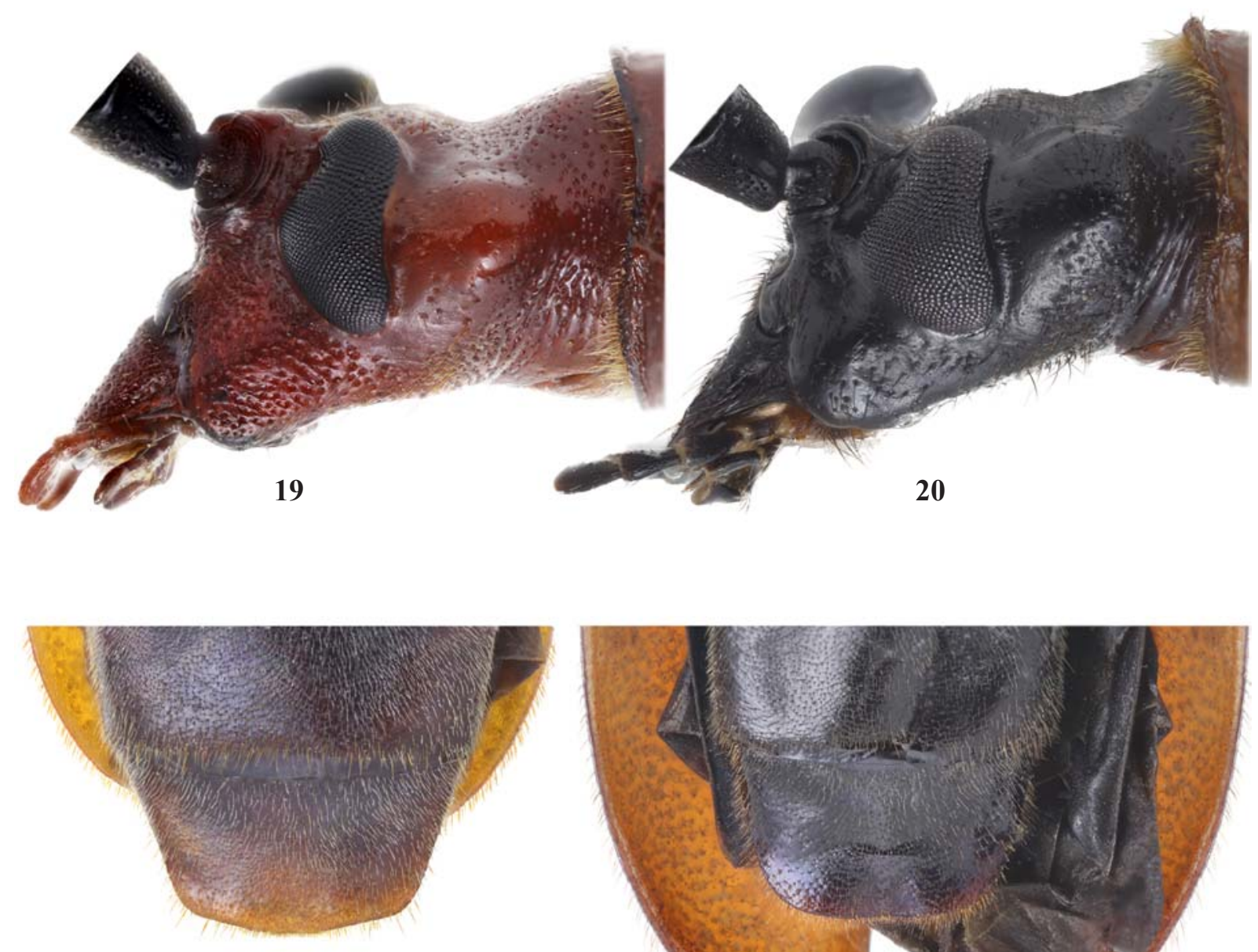

21

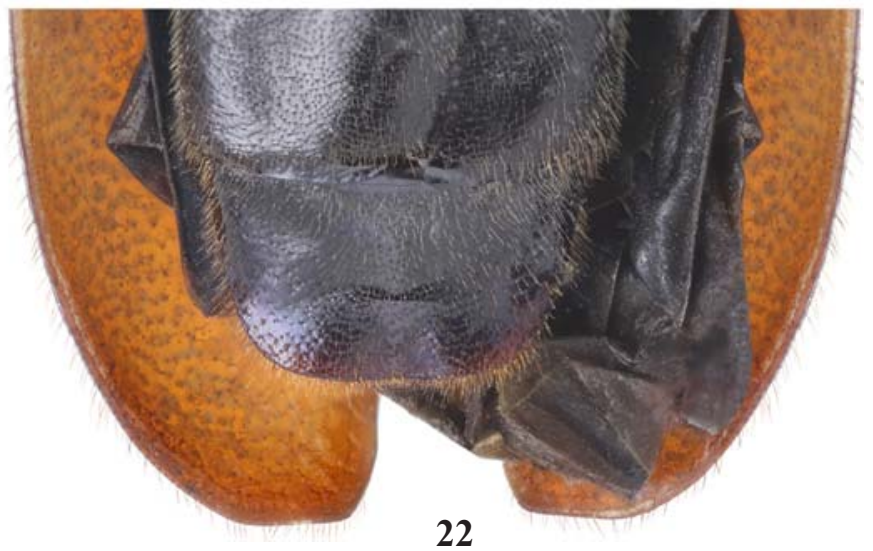

Figs 17-22. Neorhamnusium ssp., holotypes: 17, $21-N$. rugosipenne; 18, $22-N$. shaanxiensis sp.n.; $19-N$. wuchaoi sp.n.; $20-$ N. melanocephalum sp.n.; $17-20$ - head, lateral view; 21 - apex of the abdomen, ventral view; 22 - apices of the abdomen and elytra, ventral view; 17-18, 21-22 - males; 19-20 - females.

Рис. 17-22. Neorhamnusium ssp., голотипы: 17, $21-N$. rugosipenne; 18, $22-N$. shaanxiensis sp.n.; $19-N$. wuchaoi sp.n.; $20-$ N. melanocephalum sp.n.; 17-20 - голова сбоку; 21 - вершина брюшка снизу; 22 - вершины брюшка и надкрылий снизу; 17-18, 21-22 - самцы; 19-20 - самки. 
on either side lateral to gula and lower one-quarter of submentum with sharp, oblique folds and rough, partly coarse puncturation; antennae long, almost reaching the last one-sixth of elytra; antennomere 5 considerably broadened in apical part on external side and narrowed towards apex; length ratio of antennomeres 1-11, 69: 21: 44: 39: 79: 79: 79: 77: 73: 75: 102.

Pronotum strongly transverse, at level of lateral tubercles 1.6 times as wide as long; base 1.14 times as wide as long and 1.21 times as wide as width at apex, length only 1.06 times exceeding width at apex; with very well-developed lateral tubercles so that elytra at humeri only 1.24 times as wide as pronotum at their level; disk with a pair of large, but not strongly convex, moderately connivent tubercles flanking midline, also with a small, but nonetheless distinct median tubercle; large discal tubercles on external side strongly, somewhat uneven impressed and there with a very clear, mostly rough puncturation; without median groove; in addition, external side of discal tubercles with a clear, somewhat heterogeneous puncturation, most abundant at base and less dense at apex, very sparse or completely invisible in central part of disk, including both on inner and dorsal sides of discal tubercles.

Scutellum moderately deeply sunken between adjacent parts of elytra, triangular, rounded at apex, in apical part slightly impressed, with individual, unclear punctures.

Elytra quite elongated, 2.77 times as long as humeral width, subparallel-sided, thereby in basal one-third barely narrowed towards apex, while in apical part barely broadened towards apex; lateral to scutellum tuberculiform elevated; at apex rounded on external side and truncate towards suture; noticeably diverging along suture at apex; each elytron with two well-expressed ribs on disk and mostly clear subsutural rib; with a sharp, dense and confluent puncturation forming mostly well-developed, very clear, predominantly transverse, rugose sculpture, especially strongly expressed in apical part.

Prosternum in apical part with sharp, transverse folds, prosternal process narrow between coxae, moderately broadened at apex; mesosternum with a clear, transverse rugose sculpture, mesosternal process about 2 times as wide as prosternal process between coxae; metasternum with a clear, predominantly small, dense puncturation forming at median suture, in its basal part, oblique wrinkles; most of visible sternites with a less distinct puncturation than on metasternum; last (visible) sternite at apical margin distinctly roundish, widely rounded on sides, very clearly impressed mainly in apical half, with clear, somewhat heterogeneous, mostly rough, predominantly moderately dense punctures, many of these being larger than on previous sternite.

Legs slender, long; femora not claviform.

Sparse, more or less long, erect, light setae mainly on head and sides of pronotum; both apical and basal margins of prothorax with abundant, yellowish and golden setae; elytra mainly with relatively short, suberect, sparse, golden-reddish setae; venter beset with numerous, predominantly recumbent, partly suberect, light setae; setation of antennae and legs developed moderately.

Genitalia. Tergite 8 moderately narrowed towards apex, at apical margin quite wide, almost straight truncate, on sides clearly angulate, as in Fig. 38; penis moderately strongly, more or less evenly curved in lateral view, as in Fig. 44; tegmen as in Fig. 42, each paramere moderately narrow, on inner side 5.9 times as long as width in the middle of apical one-third, on inner side noticeably uneven, most clearly so in middle area, in apical part predominantly with long and very long, light setae, as in Figs 40, 42.

DISTRIBUTION. China: Shaanxi Province.
BIONOMICS. The holotype was taken in July at an altitude of about $1700-1800 \mathrm{~m}$.

ETYMOLOGY. The name of the new species is derived from Shaanxi Province, China, the terra typica.

\section{Neorhamnusium wuchaoi Miroshnikov et Lin, sp.n.} Figs 9, 12, 16, 19, 25, 30, 33, 35.

MATERIAL. Holotype $q$ [IZAS, IOZ(E)1904800], China, Beijing, Mentougou, Xiaolongmen, $1130 \mathrm{~m}, 39^{\circ} 57^{\prime} \mathrm{N} / 115^{\circ} 26^{\prime} \mathrm{E}$, 22.VI.2012, leg. Chao Wu.

DIAGNOSIS. The new species seems to be especially similar to $N$. rugosipenne, but differs by a pair of discal tubercles of the pronotum being much less connivent with each other and clearly less convex (Figs 34-35), in the presence of a distinct, median, longitudinal groove, the significantly more sharp, median groove between the antennal tubercles and eyes (Figs 13, 16, 28, 30-31, 33), the noticeably less strongly developed rugose sculpture of the elytra, the less strongly expressed longitudinal ribs on their disk, the mandibles much more angulate at the external margin and with a tuberous, stepshaped protrusion clearly more strongly developed in the middle part (Figs 13, 16), and the almost entirely black antennae and mostly black legs (Figs 7-9, 10, 12). Neorhamnusium wuchaoi sp.n. can also be compared to N. shaanxiensis sp.n., but differs in the structure of the pronotum, including its proportions (Figs 29-30) which are clearly more similar to those in N. rugosipenne, by a pair of discal tubercles slightly impressed on the external side, almost like in $N$. rugosipenne, with a clearly smaller puncturation (Figs 29-30, 32-33), by the presence of a median groove, as well as by the elytra being less strongly elongated and completely rounded at the apex (partly not truncate) (Figs 8-9, 22), and thus resembling N. rugosipenne, but with yet a sharper distinction compared to $N$. rugosipenne in the weak development of a rugose sculpture, the undeveloped median discal tubercle of the pronotum, the glossy shine of most of the head and of pronotum (Figs 14, 16, 29-30, 32-33), like in N. rugosipenne. Besides this, in the comparison with these two species, $N$. wuchaoi sp.n., shows a much more coarse puncturation of the head dorsally (Figs 1314, 16, 28-33), the clearly longer genae significantly (almost 1.4 times) exceeding the transverse diameter of the eye (Fig. 17-19), the distinctly more strongly expressed and mostly clearly excavated submentum with a peculiar sculpture (Fig. 23-25). However, these differences are possibly related to the structure of the head in different sexes, i.e. in the female of $N$. wuchaoi sp.n. and in the males of $N$. rugosipenne and $N$. shaanxiensis sp.n. At the same time, the ratio of length of genae to transverse diameter of eye in N.wuchaoi sp.n. (Fig. 19) differs strongly (nearly 1.4:1) even from that in the female of N. melanocephalum sp.n. (Fig. 20), in which this ratio is subequal, ca 1:1 (see above). The somewhat peculiar shape of the last segment of the maxillary and labial palpi in $N$. wuchaoi sp.n. (Figs 16, 25) is also noteworthy, this differing clearly not only from that of the males of $N$. rugosipenne (Figs 13,23) and $N$. shaanxiensis sp.n. (Figs 14, 24), but also from that in the females of $N$. melanocephalum sp.n. (Figs 6, 26) and N. taiwanum (Figs 5, 27), as well as from that of the male of this latter species.

DESCRIPTION. Female. Body length $20.8 \mathrm{~mm}$, humeral width $6.0 \mathrm{~mm}$. Head almost entirely, mouthparts mainly, pronotum, except for black apical margin complete and basal margin partly, scutellum, for blackish the very base, elytra entirely, prosternum, except for blackish apical margin, mesosternum, procoxae, mesocoxae and mesofemora partly, profemora and protibiae mostly red tones; antennae, except for to varying degree reddish four last antennomeres, eyes, metaster- 


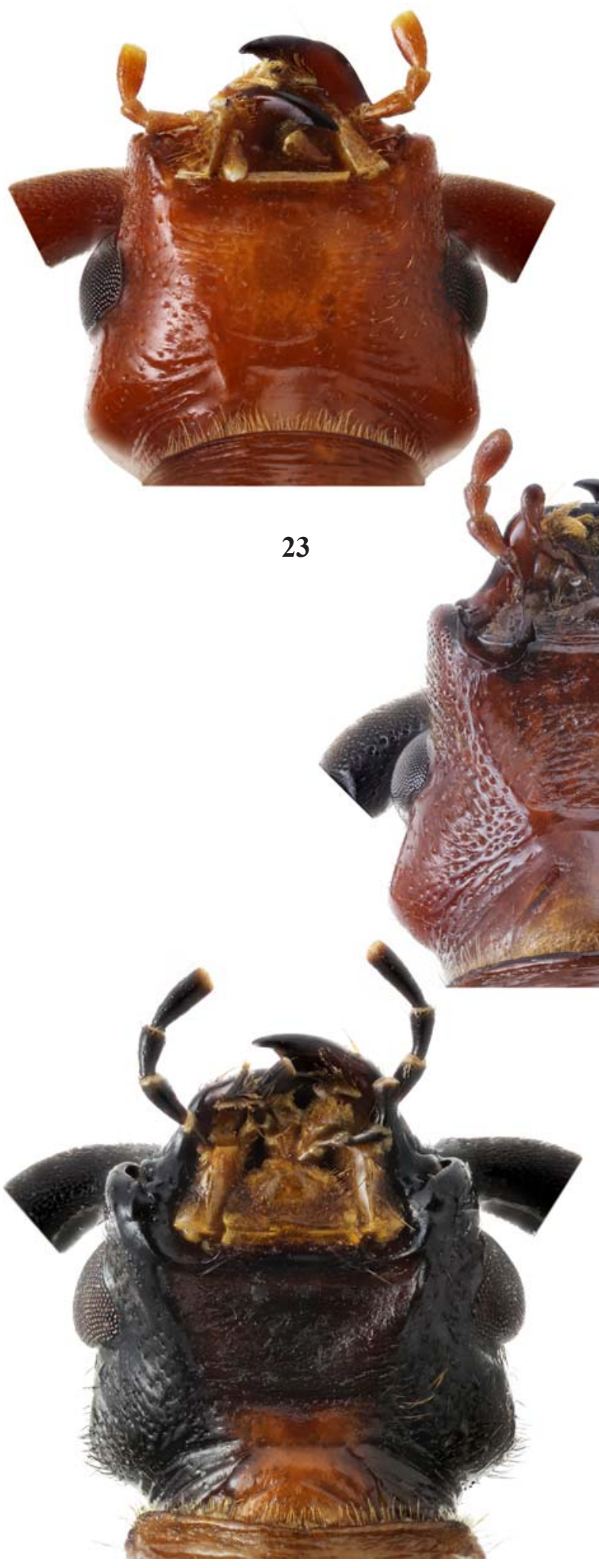

26
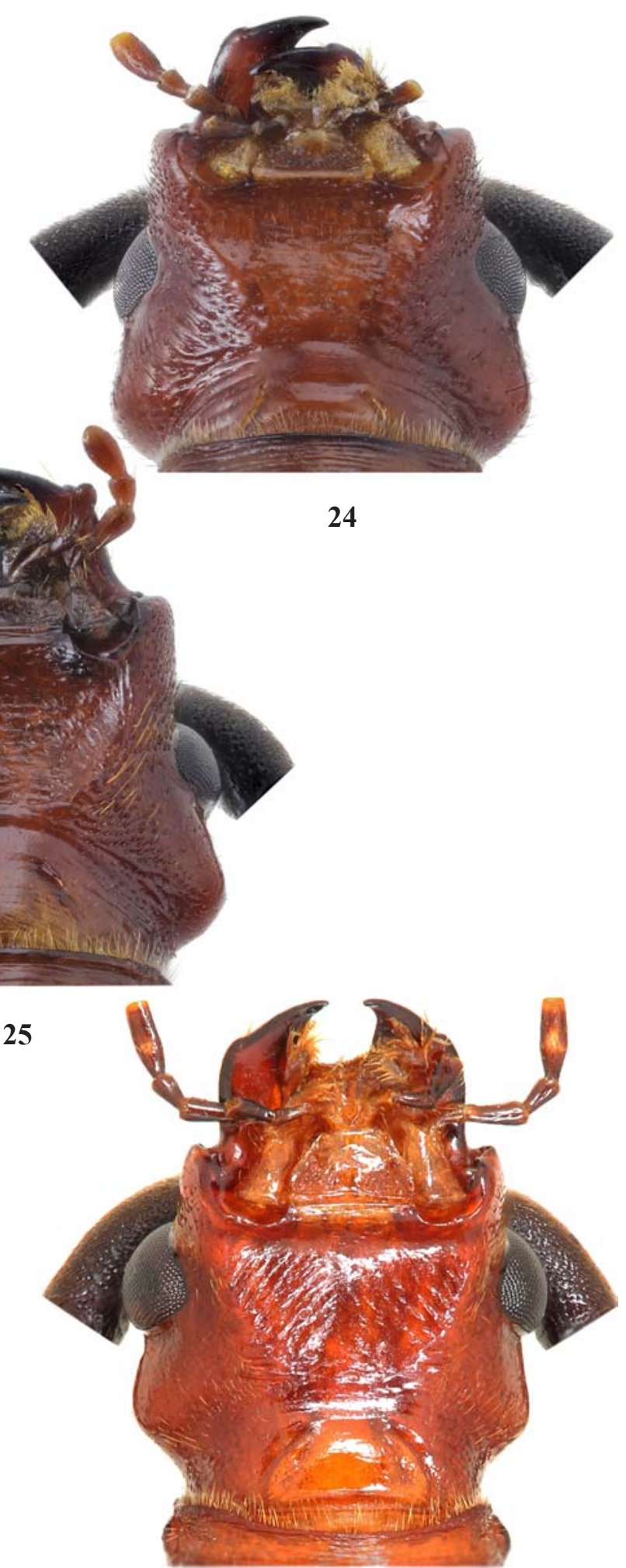

27

Figs 23-27. Neorhamnusium ssp., head, ventral view: $23-N$. rugosipenne; $24-N$. shaanxiensis sp.n.; $25-N$. wuchaoi sp.n.; $26-$ N. melanocephalum sp.n.; 27- N. taiwanum (photograph by Nobuo Ohbayashi); 23-26 - holotypes; 23, 24 - males; 25-27- females.

Рис. 23-27. Neorhamnusium ssp., голова снизу: $23-N$. rugosipenne; $24-N$. shaanxiensis sp.n.; $25-N$. wuchaoi sp.n.; $26-N$. melanocephalum sp.n.; 27- N. taiwanum (фотография Нобуо Обаяси); 23-26 - голотипы; 23, 24 - самцы; 25-27- самки. 
num, sternites, metacoxae, metafemora and metatibiae complete, mesosternum almost entirely, procoxae, mesocoxae and mesofemora mostly, profemora and protibiae partly, mesotibiae almost complete, tarsi, except for reddish apex of last tarsomere black; both head dorsally and pronotum with a strong, elytra with a weaker, glossy shine.
Head medium-size, at least together with prothorax not appearing small relative to elytra; with very well-developed antennal tubercles; in area of occiput strongly depressed, behind temples insensibly merging with neck; with a very sharp, deep, median groove between antennal tubercles and eyes; dorsally predominantly with a coarse or quite rough,

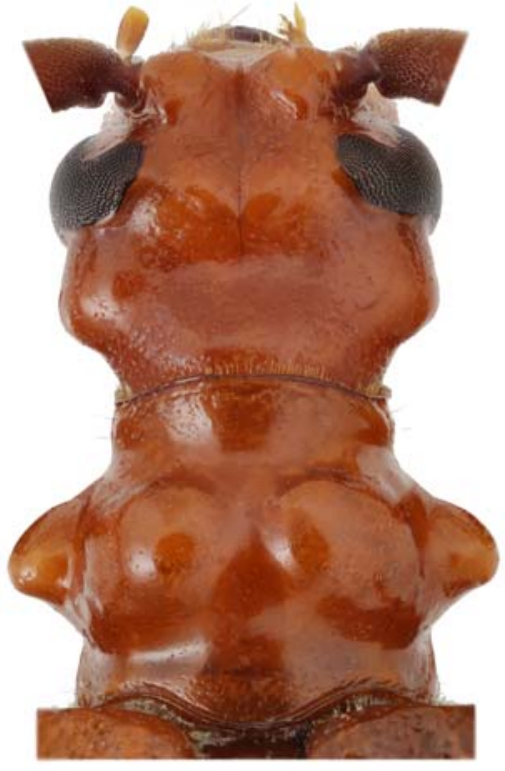

28

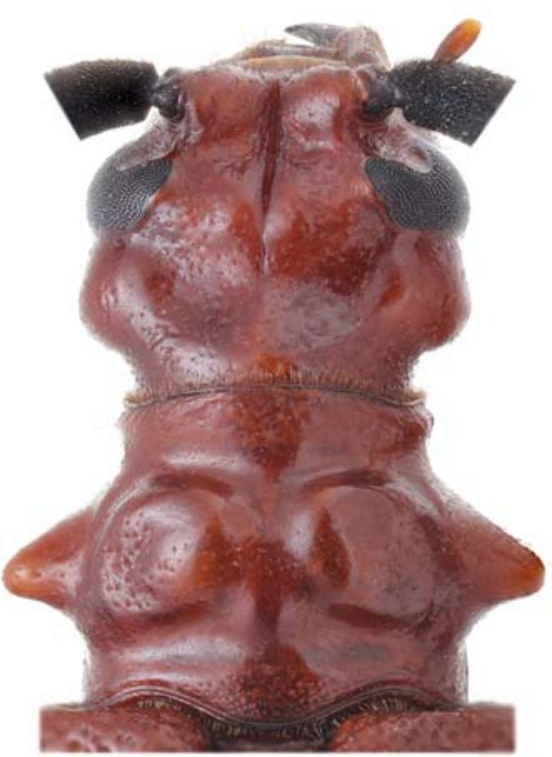

29

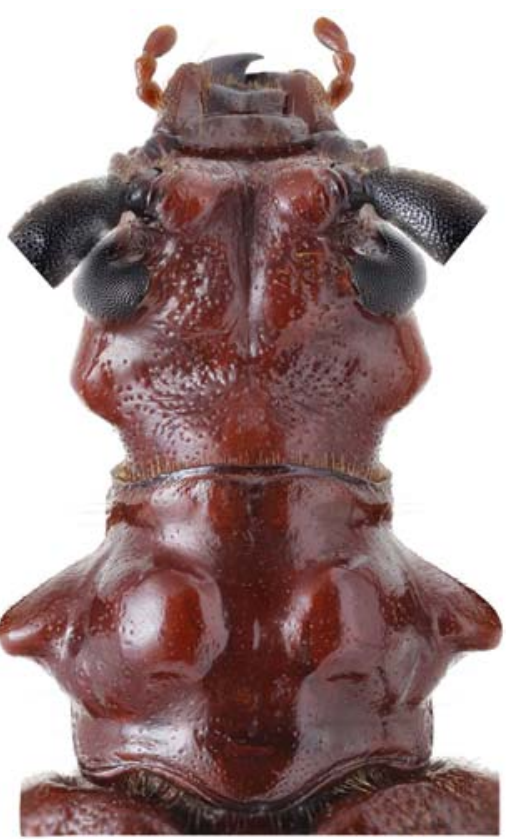

30

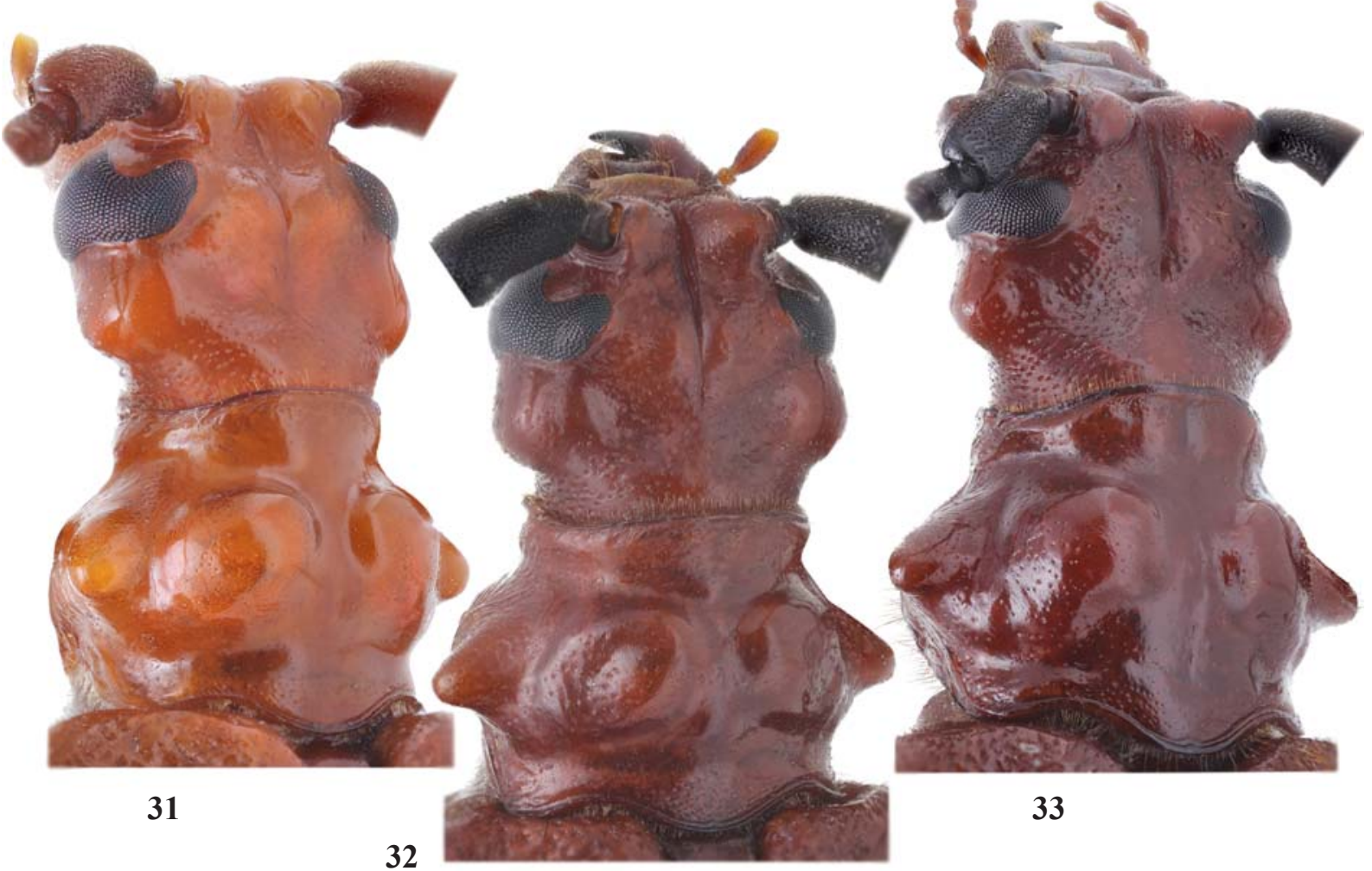

Figs 28-33. Neorhamnusium ssp., holotypes: 28, $31-N$. rugosipenne; 29, $32-N$. shaanxiensis sp.n.; 30, $33-N$. wuchaoi sp.n.; 28-30 - head and pronotum, dorsral view; 31-33 - the same, dorsolateral view; 28-29, 31-32 - males; 30, 33 - female.

Рис. 28-33. Neorhamnusium ssp., голотипы: 28, $31-N$. rugosipenne; 29, 32 - N. shaanxiensis sp.n.; 30, $33-N$. wuchaoi sp.n.; 28-30 — голова и переднеспинка сверху; 31-33 — то же, сверху и сбоку; 28-29, 31-32 — самцы; 30, 33 - самка. 
sharply expressed, irregular, in places dense puncturation; genae long, 1.38 times as long as transverse diameter of eye and even barely longer than temples, with a coarse or rough, mainly dense puncturation, partly forming rugose sculpture; temples moderately long, very clearly broadened backwards, mostly with sparse, rough punctures, denser and coarser ventrally; eyes emarginate to depth not more than $1 / 3$ of their transverse diameter; mandibles at external margin in middle part with a very well-expressed, tuberous, step-shaped protrusion; submentum strongly depressed anteriorly, very clearly impressed on sides, in general forming a very sharply expressed excavation, this being wide anteriorly, gradually narrowing and also evenly disappearing towards gula, mostly with transverse wrinkles and rough, sparse punctures, on sides with longitudinally oblique wrinkles, especially clear in anterior part of sides; gula with clear, transverse, heterogene- ous folds and small punctures; on either side lateral to gula with coarse folds and a sharp puncturation, on either side lateral to submentum with a sharp, heterogeneous, coarse or rough, predominantly dense and confluent puncturation, partly forming heterogeneous wrinkles; antennae approximately reaching the middle of elytra; antennomere 2 distinctly longitudinal; antennomere 5 longest, considerably broadened in apical part on external side and narrowed towards apex; length ratio of antennomeres $1-11,56: 21: 43: 35: 67: 62: 64$ : 59: 58: 49: 54 .

Pronotum clearly transverse, at level of lateral tubercles 1.46 times as wide as long; base subequal in width and length and 1.2 times as wide as width at apex; with well-developed lateral tubercles so that elytra at humeri 1.28 times as wide as pronotum at their level; disk with a pair of large, very widely spaced, moderately convex tubercles flanking midline, with-
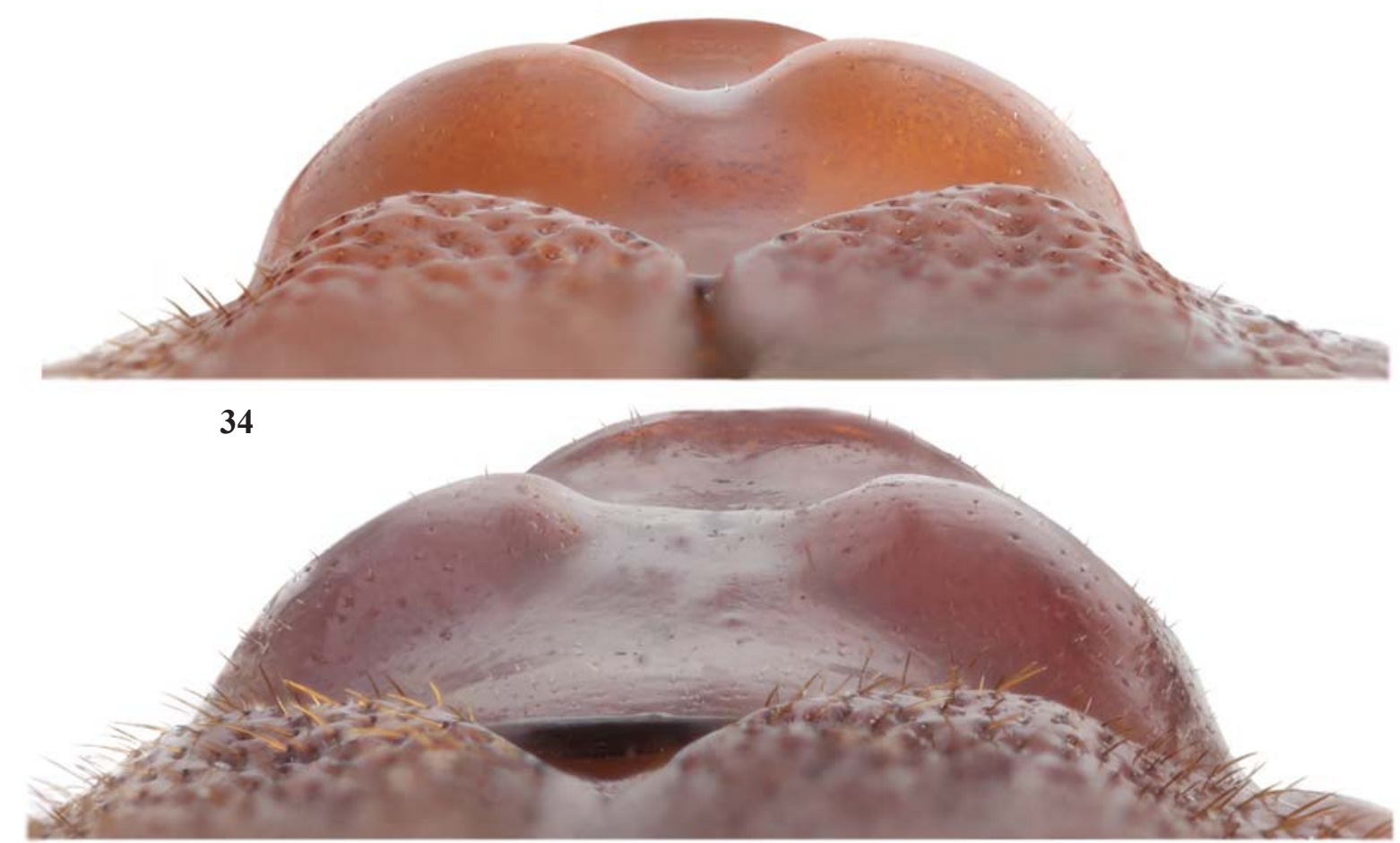

35

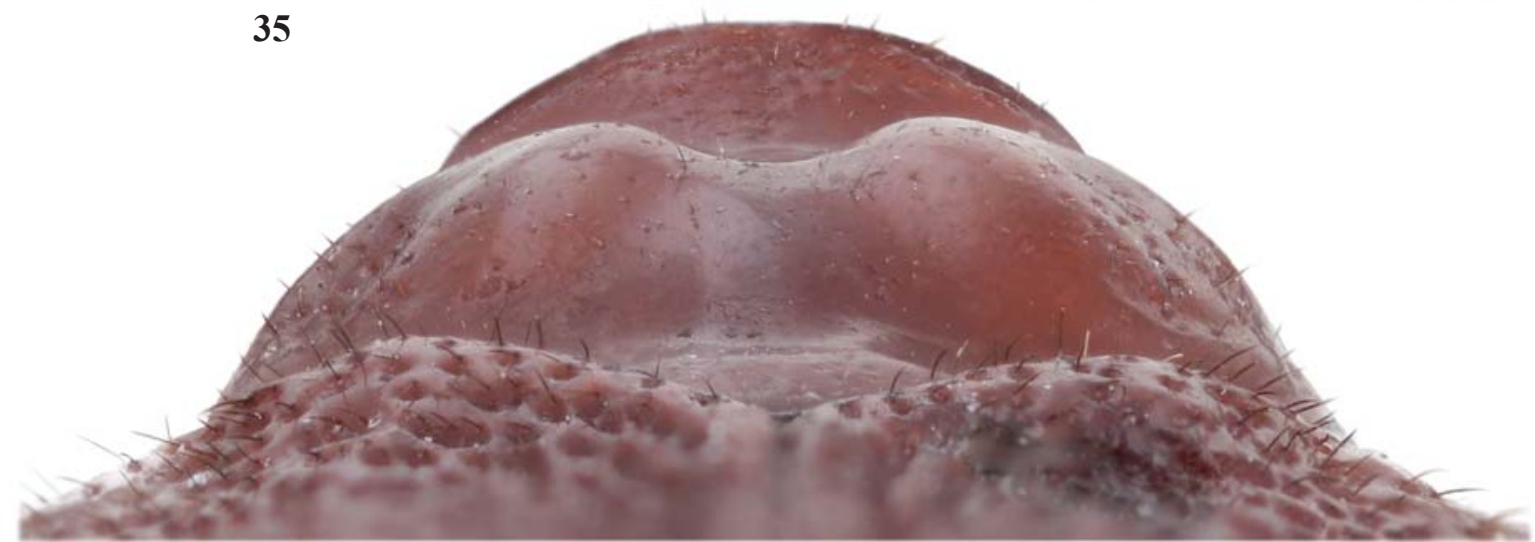

36

Figs 34-36. Neorhamnusium ssp., holotypes, pronotum, back view: $34-N$. rugosipenne; $35-N$. wuchaoi sp.n.; $36-N$. shaanxiensis sp.n.; 34,36 - males; 35 - female.

Рис. 34-36. Neorhamnusium ssp., голотипы, переднеспинка сзади: $34-N$. rugosipenne; $35-N$. wuchaoi sp.n.; $36-N$. shaanxiensis sp.n.; 34, 36 - самцы; 35 - самка. 


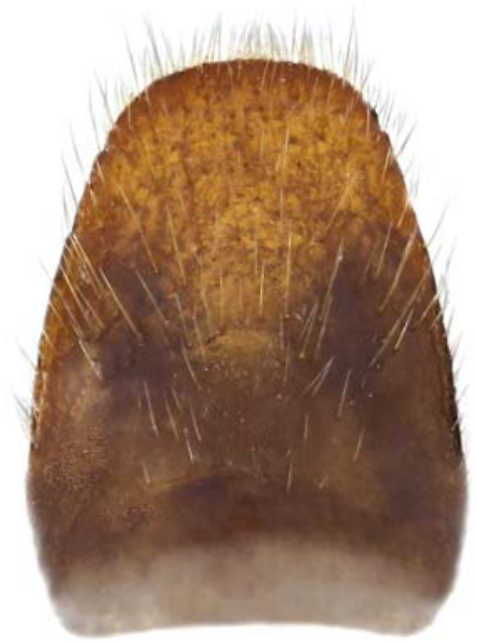

37

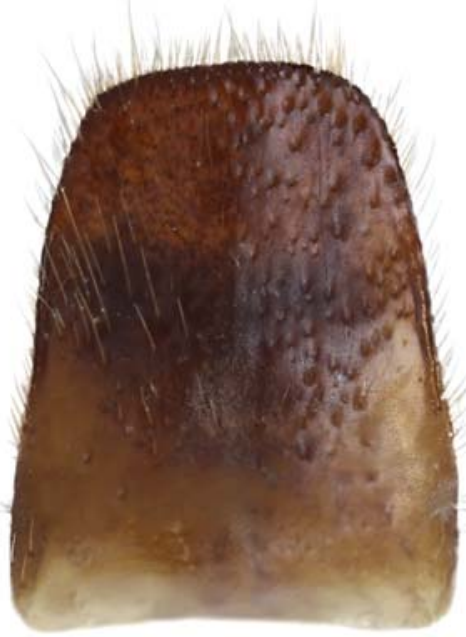

38

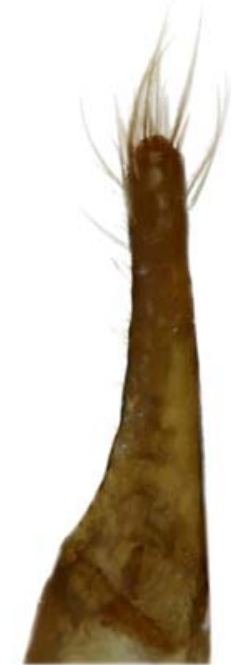

39

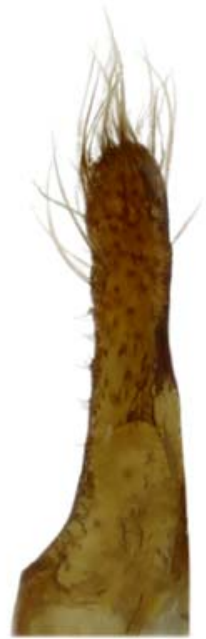

40

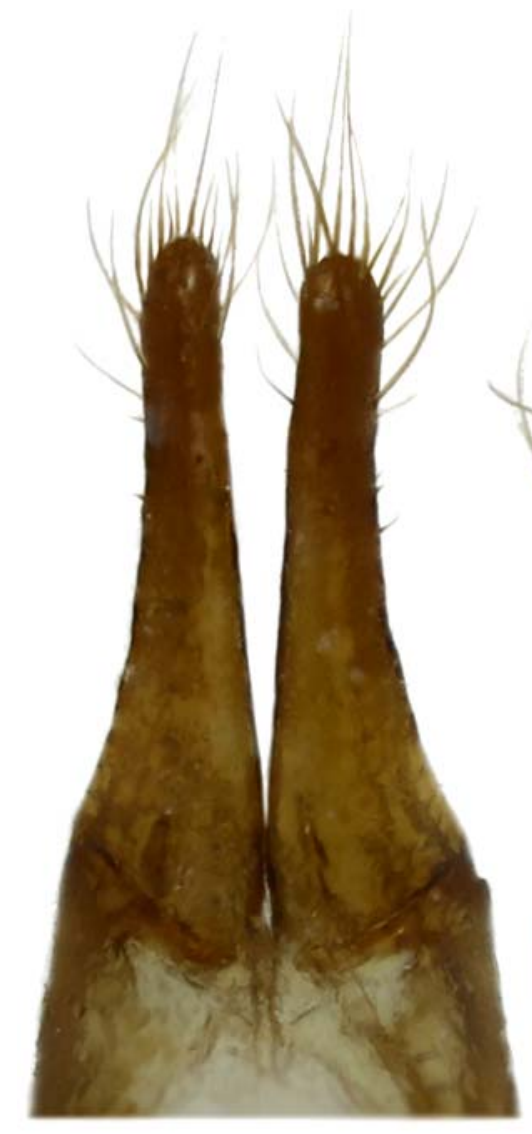

41

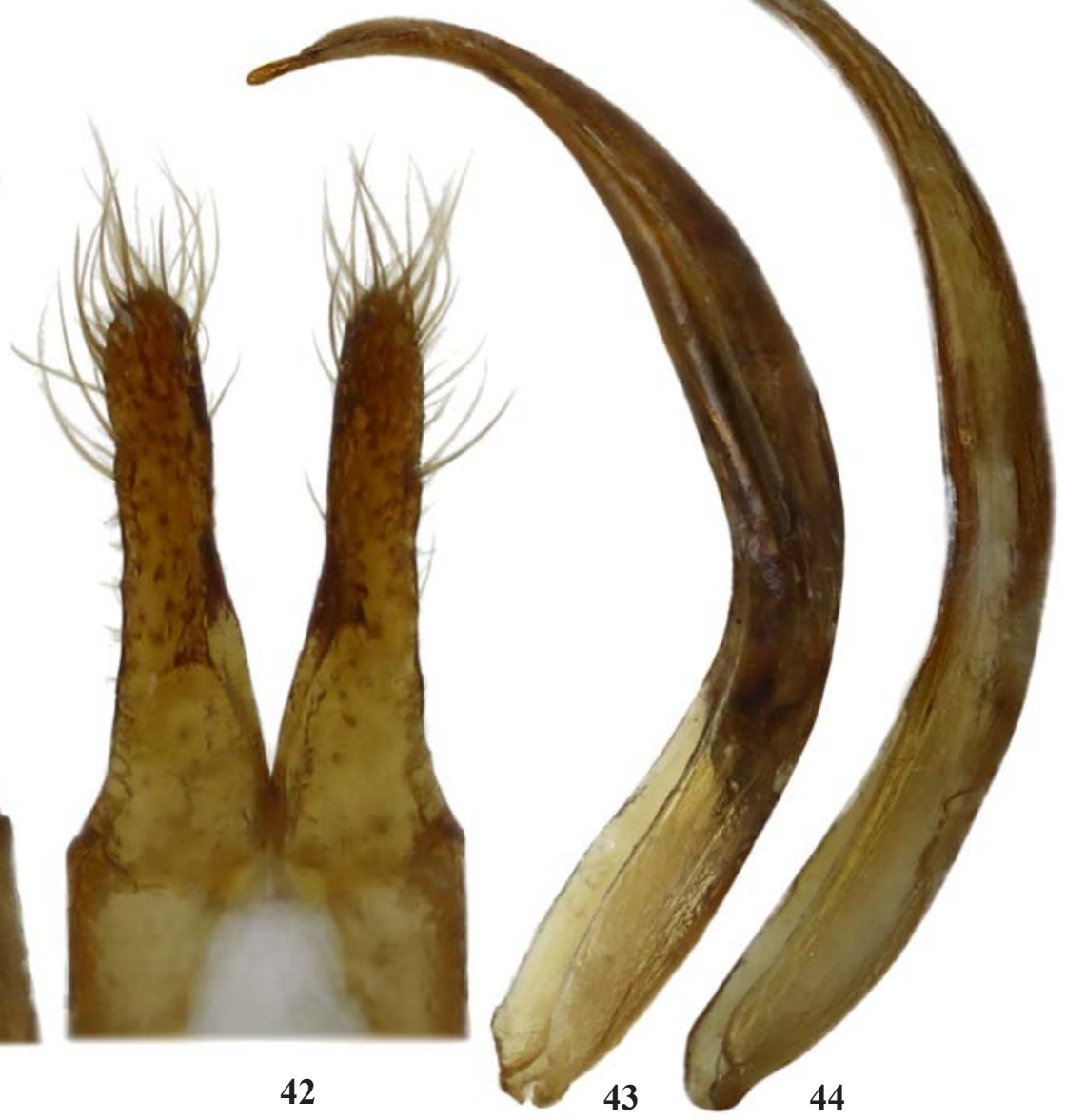

Figs 37-44. Neorhamnusium ssp., holotypes, males, genitalia: 37, 39, 41, 43-N. rugosipenne; 38, 40, 42, 44 - N. shaanxiensis sp.n.; 37-38 - tergit 8, dorsal view; 39-40 - left paramere, dorsal view; 41-42 - apical part of the tegmen, dorsal view; 43-44 - penis, lateral view.

Рис. 37-44. Neorhamnusium ssp., голотипы, самцы, гениталии: 37, 39, 41, 43 - N. rugosipenne; 38, 40, 42, 44 - N. shaanxiensis sp.n.; 37-38-8-й тергит сверху; 39-40- левая парамера сверху; 41-42 - вершинная часть тегмена сверху; 43-44- пенис сбоку. 
out median tubercle; discal tubercles on external side only slightly impressed and there with a small puncturation; with a clear, but gentle, median groove starting from apex and noticeably not reaching the base; in addition, external side of discal tubercles with a clear, small, somewhat heterogeneous puncturation, denser both at base and apex, very sparse, partly or completely invisible in central part of disk, including both on inner and dorsal sides of discal tubercles.

Scutellum deeply sunken between adjacent parts of elytra, triangular, rounded at apex, in apical part noticeably impressed, without punctures.

Elytra 2.46 times as long as humeral width, subparallelsided; lateral to scutellum noticeably, but not strongly tuberculiform elevated; on external sides of apex widely rounded; sutural angle narrowly rounded; noticeably diverging along suture at apex; each elytron with two weakly expressed ribs on disk and distinct subsutural rib only in apical one-third; with a sharp, dense and confluent puncturation forming partly more or less clear rugose sculpture.

Prosternum in apical part with sharp, transverse folds, prosternal process narrow between coxae, considerably broadened at apex; mesosternal process strongly narrowed towards apex; metasternum with a very clear, dense puncturation, median suture mostly clearly keel-shaped elevated; visible sternites, except for last one also punctured, puncturation being slightly larger; last (visible) sternite with partly larger and sparser punctures than other sternites, at apical margin widely truncate and with a weak emargination, as well as with a weak, but distinct impression in apical part.

Legs slender, long; femora not claviform; metatarsomere 1 noticeably longer than next two metatarsomeres combined.

Sparse, more or less long, erect, light setae mainly on head and sides of pronotum; both apical and basal margins of prothorax with abundant, golden setae; elytra mainly with relatively short, suberect, sparse, golden-reddish setae; venter beset with numerous, predominantly recumbent, partly suberect, light setae; setation of antennae and legs developed moderately.

DISTRIBUTION. China: Beijing.

BIONOMICS. The holotype was taken in the second half of June on a dry tree trunk at an altitude of a little more than $1100 \mathrm{~m}$.

REMARKS. Despite the great similarity of this new species to the geographically closest $N$. rugosipenne in habitus, in some details of the structure of the pronotum, including its proportions, partly the sculpture of the discal tubercles, as well as in shape of the elytra and a number of the other features, we are still fairly confident of an independent species status of $N$. wuchaoi sp.n. A relative stability can be traced among the diagnostic features described above, such as the location of the discal tubercles of the pronotum, the shape of their convexity and the character of the sculpture on the elytra even in the three specimens of $N$. taiwanum which pictures are at our disposal (see above). This is a series representing this congener, in which both sexes are thereby also available. Thus, in the two males, including the holotype, and in one female of $N$. taiwanum, the distance between the widely spaced discal tubercles of the pronotum is about the same, with no significant differences being observed in shape of these tubercles dorsally; a rugose sculpture on the elytra and the longitudinal ribs on their disk are likewise very similar. Besides this, the lack of significant distinctions in the coloration of the antennae and legs in these three specimens is also noteworthy. All this seems to be of paramount importance for recognizing $N$. wuchaoi sp.n., certainly also taking into account its other characteristics mentioned above.
ETYMOLOGY. The new species is named after the collector, Mr. Chao $\mathrm{Wu}$, a young man with a good knowledge of the Beijing insect fauna, currently working on the taxonomy of Chinese mantes (Mantoidea).

\section{Key to SPECIES OF NEORHAMNUSIUM}

1. Elytra considerably broadened towards apex in apical part (Figs 1, 3-4); at least all tibiae entirely black............ 2

- Elytra approximately parallel-sided (Figs 7-12); at least protibiae entirely or partly red tones ......................... 3

2. Pronotum with more strongly developed lateral tubercles (Figs 1, 3, 5); both head and scutellum red tones (Figs 1, $3,5,27)$; at least profemora partly or mostly red tones (Figs 1, 3) .................................... N. taiwanum Hayashi

- Pronotum with less strongly developed lateral tubercles (Figs 4, 6); head mostly and scutellum complete black (Figs 4, 6, 20, 26); all femora and tibiae entirely black (Fig. 4) ............................. N. melanocephalum sp.n.

3. Elytra less strongly elongated, not more than 2.6 times as long as humeral width, at apex fully rounded (Figs 7, 9); pronotum narrower, at level of lateral tubercles 1.38-1.46 times as broad as long, there subequal to or barely shorter than width at base, not less than 1.2 times as long as width at apex (Figs 28, 30); large discal tubercles of pronotum barely impressed on external side and there with a clearly, smaller puncturation (Figs 28, 30, 31, 33); median discal tubercle of pronotum not or barely expressed; head at least dorsally and pronotum with a strong glossy shine (Figs $13,16,28,30-31,33)$........................................... 4

- Elytra more strongly elongated, almost 2.8 times as long as humeral width (Fig. 8), at apex truncate partly (Figs 8, 11, 22); pronotum wider, at level of lateral tubercles 1.6 times as broad as long, there clearly shorter than width at base and only barely longer than width at apex (Fig. 29); large discal tubercles of pronotum strongly impressed on external side and there with a clearly, larger puncturation (Figs 29, 32); small median discal tubercle of pronotum well-expressed; head at least dorsally and pronotum with a rather dull shine (Figs 14, 29, 32) ............. N. shaanxiensis sp.n.

4. Disk of pronotum with clearly more convex and much more connivent with each other tubercles (Fig. 34), without median groove; elytra with more strongly expressed longitudinal ribs on disk and more clear rugose sculpture, especially in apical one-third; several basal antennomeres entirely, anterior and middle legs almost completely, posterior legs at least partly red tones (Figs 7,10$)$.........

N. rugosipenne (Pic)

- Disk of pronotum with clearly less convex and much less connivent with each other tubercles (Fig. 35), with a gentle, but distinct median groove; elytra with less strongly expressed longitudinal ribs on disk and less clear rugose sculpture, even in apical one-third; antennae, except for several apical antennomeres, anterior and middle legs partly, posterior legs almost completely black (Figs 9, 12) ....................................... N. wuchaoi sp.n.

ACKNOWLEDGEMENTS. We are very grateful to Maxwell V.L. Barclay (BMNH), Thierry Deuve, Azadeh Taghavian and Gérard L. Tavakilian (MNHN), Alexey A. Gusakov (ZMUM) for the opportunity to study the museum material, to Sergey V. Murzin (Moscow, Russia) who has provided some specimens from his private collection and has arranged the receipt of another material for research. Our sincere thanks also go to Wen-I Chou, Nobuo Ohbayashi and Shigehiko Shiyake for several pictures of $N$. taiwanum, in- 
cluding the holotype, and valuable data about this species they shared, to Hao Xu (Simianshan, Chongqing, China) and Hongliang Shi (Beijing Forestry University, Beijing, China) who helped with the elucidation of the modern name and whereabouts of the type locality of $N$. rugosipenne. The second author is most grateful to Hongliang Shi and Chao $\mathrm{Wu}$ (Beijing, China) for donating the holotype of $N$. wuchaoi sp.n. to IZAS. We are deeply indebted to Kirill V. Makarov (Moscow Pedagogical State University, Russia) who has helped with the preparation of all photographs, except for N. taiwanum.

\section{References}

Catalogue of Palaearctic Coleoptera. Vol. 6. Chrysomeloidea 2010. // I. Löbl, A. Smetana (eds.). Stenstrup: Apollo Books. $924 \mathrm{p}$.

Cebeci H., Özdikmen H. 2010. A synopsis on the genus Rhamnusium Latreille, 1829 with a new record (Coleoptera: Cerambycidae) for Anatolian fauna from a new host plant, Liquidambar orientalis Miller (Hamamelidaceae) // Munis Entomology \& Zoology. Vol.5. No.1. P.131-139.

Chou W.-I. 2004. [The Atlas of Taiwanese Cerambycidae]. Owl Publ. House, Taipei. 408 p. [in Chinese].

Etapes des Voyages du P. Licent S.J. dans la Chine 1914-1937. 1984. Natural Museum of Tianjin, Archives. 130 p. +8 p., Liste des sons chinois [in French with Chinese explanations].

Gressitt J.L. 1951. Longicorn beetles of China // Lepesme P. (ed.) Longicornia. Études et notes sur les Longicornes. Vol.2. Paris: Paul Lechevalier. 667 p. +22 pls.
Hayashi M. 1976. Studies on Asian Cerambycidae (Coleoptera). $1 / /$ Bulletin of the Osaka Jonan Women's Junior College. Vol.11 (November). P.1-24.

Hayashi M., Ando K. 1976. Neorhamnusium taiwanum sp.n. // In: Hayashi M. Studies on Asian Cerambycidae (Coleoptera). $1 / /$ Bulletin of the Osaka Jonan Women's Junior College. Vol.11 (November). P.2-3.

Hayashi M., Nakamura S., Makihara H., Saito A., Chu Y.-I. 1988. A list of Cerambycid-beetles from Taiwan, (1). Subfamilies Disteniinae, Parandrinae, Prioninae, Philinae, Aseminae, Spondylinae, Lepturinae // Chinese Journal of Entomology. Vol.8. No.2. P.165-184.

Hayashi M. Villiers A. 1985. Revision of the Asian Lepturinae (Coleoptera: Cerambycidae). With special reference to the type specimens' inspection. Part I // Bulletin of the Osaka Jonan Women's Junior College. Vols.19-20 (October). P.1-75 + pls 1-15.

Hua L.-Z. 1982. A check list of the longicorn beetles of China (Coleoptera: Cerambycidae). Guangzhou: Zhongshan University. $159+2$ p.

Hua L.-Z. 2002. List of Chinese Insects. 2. Guangzhou: Zhongshan (Sun Yat-sen) University. $612 \mathrm{p}$

Jiang [Chiang] S.-N., Chen L. 2001. [Coleoptera Cerambycidae Lepturinae] // Fauna Sinica. Insecta. Vol. 21. Beijjing: Academia Sinica. 296 p. [in Chinese].

Mizuno K., Shiyake S. 2004. A list of Coleopterous taxa submitted by the late Dr. Masao Hayashi with type-specimens designated in his descriptions. Special publications from the Osaka Museum of Natural History. Vol.36. 82 p. +22 pls.

Pic M. 1939. Coléoptères nouveaux, principalement de Chine Cérambycides // L'Échange, Revue Linnéenne. Ann.55. No.476, hors-texte. P.1-4.

Wang Z.-C., Hua L.-Z. 2009. Collect and revision of list on longicorn beetles in China // Journal of Beihua University (Natural Science). Vol.10. No.2. P.159-192. 